\section{E-LOGOS}

ELECTRONIC JOURNAL FOR PHILOSOPHY ISSN 1211-0442

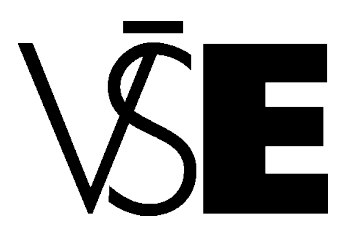

University of Economics

Prague

\title{
K Humově filosofii náboženství
}

Ján Pavlík

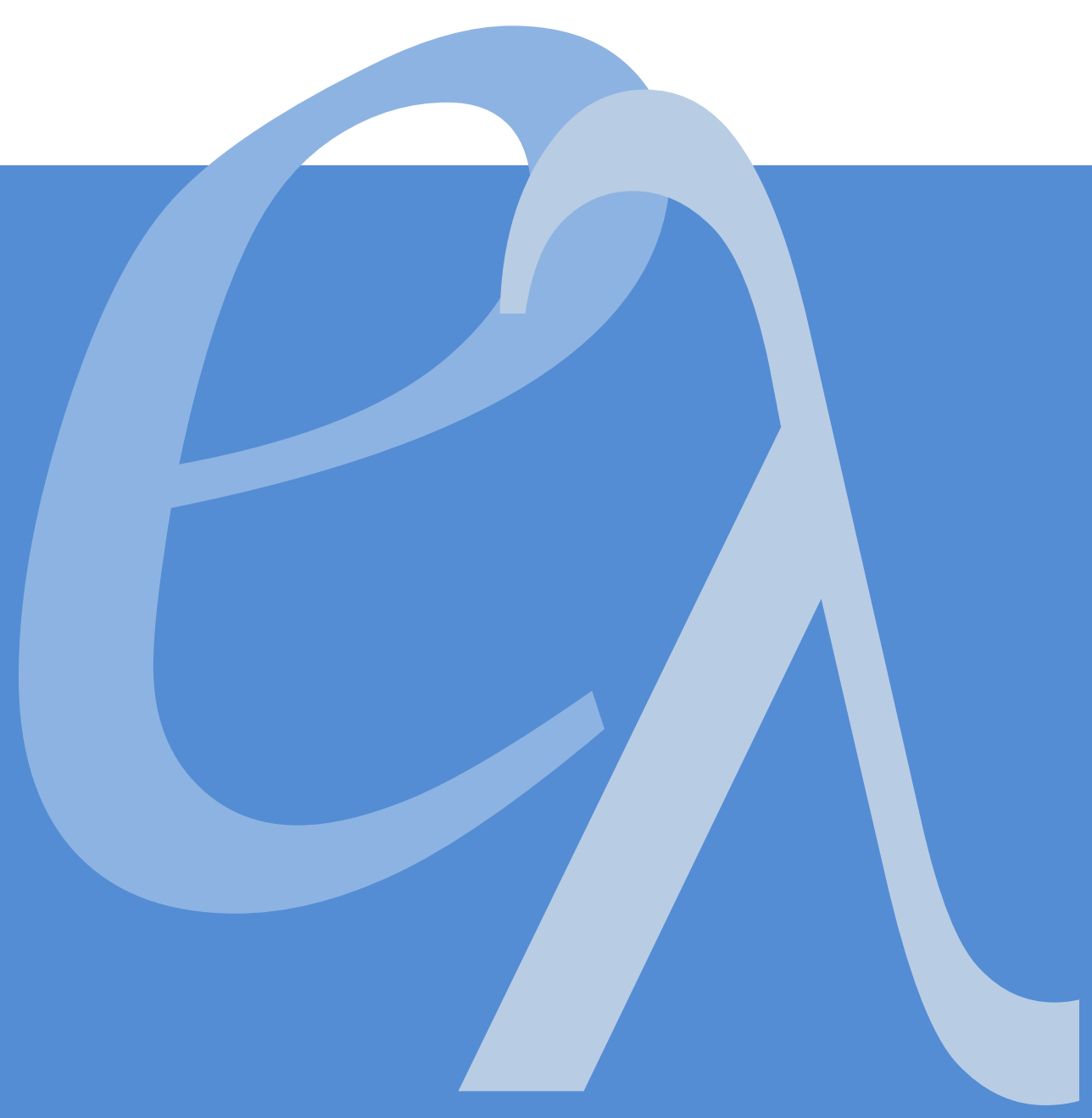




\title{
Ján Pavlík: On Hume’s Philosophy of Religion
}

\begin{abstract}
After presenting a psychological portrait of David Hume on the background of the 18th century's cultural history, the author develops the following theses: I. The sense and target of all Hume's philosophical reasoning (especially of his rejection of the ontological status of the categories of substance and cause as well as of his theory of moral sentiments) consisted in preparing the ground for a skeptical destruction of all statements concerning the being and nature of God and for substantiating the conception according to which man can live morally without being anchored in religious transcendence. II. All strongly inconsistent parts of Hume's philosophy are unified by Hume's (usually clandestine) effort to uproot religion; it is just this point of "synthesis" which enables us to grasp the meaning of them - and of the otherwise ungraspable inner unity of Hume's philosophy. III. The rejection of the ontological status of the category of substance (as treated in the context with the problem of the teleological argument for God's existence) results necessarily in Hume's anticipatory outline of the principal ideas of an evolutionary approach and theory of selforganization, which in all likelihood directly influenced the conceptions of Charles Darwin.
\end{abstract}

Keywords: David Hume, English malady, Augustan Age, conservatism, religion, skepticism, substance, cause, moral sentiment, distributive justice, God, teleology, self-organization of matter, Darwinism 


\section{Ján Pavlík: K Humově filosofii náboženství}

\section{Abstrakt}

Poté, co je ve studii podán obraz Humovy osobnosti na pozadí jeho doby, jsou v ní rozvijeny následující teze: I. Smyslem a cílem veškerého Humova filosofování (zejména jeho popření ontologického statusu kategorií substance a kauzality a jeho teorie mravních citů) je připravit půdu pro skeptickou destrukci veškerých tvrzení týkajících se existence a přirozenosti Boží a pro zdůvodnění pojetí, v souladu s nímž může člověk žít mravně bezúhonným životem i bez jakékoliv opory v náboženském transcendentnu. II. Všechny silně nekonsistentní momenty Humovy filosofie jsou sjednoceny (obvykle perfidně utajovaným) účelem, jímž je vyvrátit náboženství z kořene; právě z onoho vrcholného bodu "syntézy“ lze uchopit jejich smysl a zároveň také jinak neuchopitelnou jednotu Humovy filosofie. III. Popření ontologického statutu kategorie substance traktované v kontextu řešení problematiky teleologického důkazu Boží existence, rezultuje u Huma (takřka s železnou logikou) v anticipační nástin fundamentálních myšlenek evolučního př́stupu a teorie samoorganizace, které s velkou pravděpodobností přímo ovlivnily pojetí Charlese Darwina.

Klíčová slova: David Hume, anglická nemoc, Augustovský věk, konzervativismus, náboženství, skepticismus, substance, kausalita, mravní cit, distributivní spravedlnost, Bůh, teleologie, samoorganizace hmoty, darwinismus 
Promiňte mi tedy, že jsem předstíral, že jsem filosof.

David Hume

\section{David Hume: osobnost a doba}

Zdá se, že Fichtovo diktum „jaký člověk, taková filosofie“ platí ve v případě skeptika Huma v daleko větší míře, než je tomu při rozlišování idealistických a materialistických filosofií (což bylo původním smyslem jeho uplatňování u Fichta samotného); idealisté a materialisté mají totiž obvykle společné to, že jsou "muži systémů“, zatímco Hume je jakožto skeptik nejenom myslitelem antisystémovým, nýbrž i samotný jeho skepticismus se vyznačuje absencí vnitřní systémovosti a dokonce i prosté koherence. Pokud tedy chceme uchopit jednotící smysl jeho filosofování, musíme jej hledat nikoliv v jeho vzájemně rozporných myslitelských výkonech, nýbrž ve "žhavém jádru“ jeho osobnosti (což je metodika, kterou ve svých literárních portrétech generálně používal F. X. Šalda). I zde se však objevuje problém, protože z Humových výroků o sobě samém i ze způsobu, jímž ho posuzovali jeho současníci i následovníci, se zdá vyplývat, že Humova osobnost se žádným „žhavým jádrem“ nevyznačovala - anebo že Hume toto své "žhavé jádro“ velmi důsledně utajoval.

Ve své krátké autobiografii ${ }^{1}$ Hume uvádí, že byl člověkem mírných dispozic, ${ }^{2}$ že byl s to ovládat své nálady a že byl otevřené, společenské a radostné povahy (cheerful humour); byl též schopný náklonnosti a málo trpěl nepřátelstvím ostatních. Tvrdí také, že ve všech svých vášních byl velice umírněný; za svou převládající vášeň (ruling passion) považuje lásku k literární slávě, ale zároveň dodává, že navzdory častým zklamáním mu tato vášeň nikdy nezkazila náladu. Byl údajně dobře přijímán jak ve společnosti lidí mladých a bezstarostných, tak ve společnosti osob učených a literárních; měl prý přitom zvláštní požitek ze společnosti skromných žen. Dále o sobě sděluje, že nikdy nebyl zasažen nebo dokonce atakován „zhoubným zubem“ (baleful tooth) pomluvy a že jeho přátelé neměli nikdy př́ležitost obhajovat jakýkoliv rys jeho charakteru a chování; zmiňuje ovšem náboženské fanatiky (zealots), kteří by patrně byli velmi rádi objevili a zveřejnili jakoukoliv historku, jež by mu byla mohla uškodit, ale zároveň nás ujišt́uje, že nikdy nemohli najít takovou, která by se zdála být pravděpodobná.

\footnotetext{
${ }^{1}$ David Hume, „My Own Life“, in: T. H. Green, T. H. Grose, eds., Essays Moral, Political, and Literary by David Hume, Longmans, Green and Co., London 1889, str. 1-8 (napsáno 18. dubna 1776; 25. srpna 1776 Hume umírá).

2 To, že zde v modu jakési předběžné pohřební řeči referuje o sobě v minulém čase, ho podle vlastního doznání mělo víc posmělit $\mathrm{k}$ tomu, aby dokázal mluvit o vlastních citech.
} 
Podívejme se nyní, jak soudí o Humově osobnosti T. G. Masaryk, jehož uchvácení Humem se mj. projevovalo i tím, že si společně s manželkou Charlottou četl spisy skotského myslitele a (patrně také spolu s ní) pořídil překlad Humova díla Zkoumání principů mravnosti do němčiny. ${ }^{3}$ "Občas rád se zadívám do obličeje Humova, jak mně ho představuje stará rytina,“ praví Masaryk po letech, „a především vždy znova vidím, jak Hume při své skepsi ztloustl - slušný podbradek, bezúhonný cop a paruka divně krášlí racionalistického lamželeza. Ovšem, díváš-li se na obraz déle, vidíš, jak ústa jsou jakoby zkřivena od stálého usmívání, rty tenké, jemné, třebaže také masité; a ty oči, ty se smějí také, tak jaksi mžouravě, a přece jsou otevřeny cele, aby těch dojmů nalokaly..." 4 Tento portrét blahobytného rokokového gentlemana s copem je však v dokonalém kontrastu s pronikavostí a důsažností Humova intelektuálního výboje, který Masaryk charakterizuje následovně: „Ti, co dnes vidí v Nietzschově ,Antikristu' tak neobyčejnou sílu, at' si přečtou Huma. Nietzsche je proti němu dítě. “5 Masaryk přitom oceňuje a pokládá za "vážnou věc“, že "Hume je při své skepsi klidný", že je tedy s to psát proti náboženství, které před ním nikdo tak sžíravě nekritizoval, bez hněvu a rozčilení. Vidí v tom jeho přednost oproti Nietzschovi, který se ve svém Antikristu "zlobí a vře to v něm“, zatímco Hume „píše s klidem. S perfidním klidem.“6 Význam Humovy kritiky náboženství je tedy o to větší, že je produktem ducha, který není vůbec rozkladný, rozložený, pesimistický

${ }^{3}$ Překlad vyšel ve Vídni v r. 1883 pod názvem Untersuchungen über die Prinzipen der Moral von David Hume a zahrnoval i Masarykovy poznámky. Masarykovo uchvácení myšlenkami největšího britského filosofa vysvětloval Nejedlý tím, že Masarykovi jakožto důslednému individualistovi byla „nade vše svoboda, volnost, a to na prvém místě duševní volnost, nezávislost na komkoli a na čemkoli, na autoritách, na mínění mas, na pudech, na všem“. Jestliže Masaryk pronesl výrok, že chrání svou nezávislost i proti Bohu, pak je zřejmé, že pojímal Huma nikoliv jako autoritu, nýbrž jako vzor, ,jak možno být nezávislým, svobodným“. (Srv. Zdeněk Nejedlý, T. G. Masaryk III, Melantrich, Praha 1935, str. 136.)

4 T. G. Masaryk, Moderní člověk a náboženství, Naše Doba IV, 1897, str. 397. Masaryk ovšem zdůrazňuje, že domněle ryzí skeptik Hume nikoliv pouze boří, ale také staví, a sice etiku vycházející z mravního citu sympatie, a že tomuto citu, který je soucítěním s jinými lidmi a projevuje se libostí z toho, co prospívá všem, říká „humanita“.

${ }^{5}$ Ibid., str. 333.

${ }^{6}$ Ibid. V nedávné době vyslovil analogický soud o Humově poměru k náboženství francouzský historik Furet: „Porovnejme např́ílad Voltaira a Huma: v této dvojici není patrně Voltaire nejdůslednější odpưrce víry, vždyt' hlásá deistické učení a považuje náboženství přinejmenším za nutné pro zachování pořádku ve společnosti. Ovšem byt 'Hume podlomí důvěru v racionální důkazy existence boží, včetně finálních příčin, jež jsou tak drahé Voltairovi, nenajdeme v jeho filosofických projevech nic z protináboženské agresivity, jaká se objevuje ve spisech autora z Ferney." (François Furet, Francouzská revoluce díl I, Od Turgota k Napoleonovi 1770-1814, Argo, Praha 2004, str. 31.) Je zároveň vhodné zmínit, že znamenitý znalec britské mentality a britských dějin André Maurois naopak tvrdí, že Hume ,je typickým duchem svého století svou nenávistí vưči každému nadšení a zanícení, a to, z kterého má největší hrůzu, je zanícení náboženské“. (André Maurois, Dějiny Anglie, Lidové noviny, Praha 2003, str. 328.) 
či otrávený. Jak říká Nejedlý, Masaryk, člověk věřící, se nemůže ubránit až jisté závisti, jak nevěřící Hume je v sobě natolik klidný, vyrovnaný a harmonický. ${ }^{7}$

Přiléhavé adjektivum "perfidní", které je plodem Masarykovy št'astné empatické intuice a které bude později pro náš výklad Humova poměru k náboženství směrodatné, nicméně poukazuje na to, že teze o vnitřní harmoničnosti a bezstarostnosti skotského skeptika není zcela neproblematická. A opravdu, při bližším ohledání nalezneme indicie, že Hume trpěl tzv. anglickou nemocí (the English malady). Tuto nemoc, kterou nesmíme ztotožňovat se syfilisem (podle dobového francouzského označení), popsal klasickým způsobem skotský lékař George Cheyne (1671-1743); ${ }^{8}$ jak dokládá sám nížeuvedený název Cheynova spisu, byly jejími příznaky typicky anglický spleen, vidiny, ochabnutí ducha (resp. spíše tzv. životních duchů). ${ }^{9}$ Za prř́činu této předtím sotva známé nemoci, jejíž př́íznaky hodnotí jako děsivé (atrocious) a strašné, považoval Cheyne vlhké a proměnlivé počasí v Anglii, jedovatost (rankness) a plodnost její půdy, bohatství a těžkou stravitelnost anglických potravin, bohatství a hojnost britského obyvatelstva, nečinnost a sedavé zaměstnání př́slušníků elity (u nichž se tato nemoc většinou objevuje) a charakter života ve velkých, lidnatých, a tudíž nezdravých městech. (Náš současník Paul Kingsnorth k tomu dodává, že původně anglická nemoc se nyní stala nemocí světovou. $)^{10}$

Ze všech vyjmenovaných „strašných" př́iznaků "anglické nemoci“ byla Humovi zjevně vlastní hypochondrie; ${ }^{11}$ co se týče příznaků ostatních (hlavně

7 Z. Nejedlý, ibid., str. 130.

8 George Cheyne, The English Malady: or, A Treatise of Nervous Diseases of all Kinds, as Spleen, Vapours, Lowness of Spirits, Hypochondriacal, and Hysterical Distempers, etc., London 1733. Za upozornění na relevanci fenoménu „anglické nemoci“ pro pochopení Humovy osobnosti děkuji Tomáši Kuncovi.

${ }^{9}$ K otázce "životních duchů“ viz Ján Pavlík, Spontánní geneze jazyka, Professional Publishing, Praha 2010, str. 279.

10 Srv. Paul Kingsnorth, "How the English malady became the world's" (http://www.highbeam.com/doc/1P2-10172432.html).

11 Svědčí o tom Humův nedatovaný dopis neidentifikovanému lékaři, v němž popisuje mentální důsledky enormního intelektuálního vypětí spojeného se snahou proniknout do nejhlubších filosofických témat, kterou vyvinul ve věku 18 (!) let. Stěžuje si, že trpěl „chladem a ochabnutím (desertion) ducha", že v něm veškeré zanícení vyhaslo a že nebyl s to povznést svou mysl na takovou výši, na jaké byl s to předtím prožívat velice intenzivní intelektuální rozkoše (byl tedy postižen něčím, co bychom nyní nazvali vyhořelostí). Posléze uvádí pro něj radostné zjištění, že jeho vyhaslost nebyla způsobena defektem povahy nebo génia (sic), nýbrž nemocí, které může podlehnout každý; v této souvislosti ř́ká, že se u něj objevil ptyalismus (nadměrná slinivost), o kteréžto poruše mu lékař řekl, že je to nemoc učenců, a že se léčil se tím, že užíval pilulky proti hysterii, pil denně pintu klaretu a projezdil denně osm až deset skotských mil. Přiznává též, že se ho zmocnil žravý apetit spolu s rychlým zažíváním, což vedlo k tomu, že se jeho druhdy štíhlá postava zakulatila. (Srv. Life and Correspondence of David Hume, by John Hill Burton 1846, Edinburgh 1846, Volume I, str. 30-39.) Vydavatel Humovy korespondence Burton dodává, že zdrojem Humových úzkostí bylo vědomí, že skrze "dezerci“ ducha nebude s to ukojit hluboce zakořeněnou touhu získat filosofickou reputaci (resp. literární slávu); tyto úzkosti přirovnává Burton k úzkostem obyčejného hypochondra týkajícím se jeho tělesného zdraví. (Srv. ibid., str. 41.) Tento výklad jistěže lze akceptovat, avšak Humův dopis 
depresí), víme již, že se k nim ve své autobiografii nepřiznává. Když přes veškeré možné pochybnosti akceptujeme tento sebevýklad, můžeme se přiklonit k domněnce, že pokud Hume trpěl "anglickou nemocí", jednalo se o její zvláštní modifikaci, která se projevila i u dalších tak výrazných osobností oné doby, jakými byli Henry Fielding a geniální humorista a novátor románové kompozice Laurence Sterne; její zvláštnost spočívala v tom, že se hysterické stavy projevovaly výrony „komické energie“, tj. rozjařeností, veselostí a tendencí vidět, procitovat a zesměšňovat absurdno a groteskno. ${ }^{12}$ Třebaže ve zmíněném Humově dopise lékaři chybí přímá zmínka o náboženství, je nanejvýš pravděpodobné, že Humova „anglická nemoc“ byla projekcí intenzivní krize jeho náboženského myšlení.

Lze se tedy domnívat, že Humovým základním postojem vůči náboženskému fanatismu či horlitelství byla nikoliv Mauroisem zdơrazněná nenávist, nýbrž spíše neodolatelné nutkání zesměšňovat jeho absurditu formou kultivované ironie a perfidního sarkasmu, v nichž se projevuje jeho intelektuální nadřazenost a bezmezné pohrdání. To, že pro Huma byl náboženský fanatismus dráždivou absurditou, a nikoliv předmětem (bezmocné) nenávisti, dosvědčuje ostatně i sám Maurois, když na jiném místě říká, že Hume „nemůže pochopit, proč by mělo být náboženské přesvědčení důvodem $\mathrm{k}$ nesmiřitelnému nepřátelství o nic více, než by chápal, proč se lidé odmítají spolu potkávat na cestě. “13 Svého nutkání potírat zbraní své ironie ty, kdož jsou "chudí duchem“, tj. náboženské fanatiky (které bylo tak silné, že mu obětoval i koherenci svých filosofických tvrzení), využíval Hume k ukojení své touhy po dosažení literární slávy ovšem jen v určité omezené míře - patrně z prozíravé obavy před soustředěným protiútokem klerikálních horlivců, která ho ostatně vedla nejen $\mathrm{k}$ tomu, že se za svého života nikdy neodhodlal publikovat své Dialogy o přirozeném náboženství, ${ }^{14}$ nýbrž i k tomu, že také v tomto díle prezentuje kategorické

lékaři prozrazuje právě takovou míru zaujatosti vlastním zdravím, jaká je vlastní obyčejným, tj. "somatickým" hypochondrům.

12 Srv. Glen Colburn, ed., The English Malady: Enabling and Disabling Fictions, Cambridge Scholars Publishing, Cambridge 2008, str. 12. V této publikaci se můžeme dočíst, že "anglickou nemocí“ byli ve výrazné míře postiženi Skotové (kromě Huma i Adam Smith, Tobias Smollett a též samotný George Cheyne), kteří k tomu byli predisponování skutečností, že se na anglickém „literárním tržišti“ zmítali mezi sebepodceňováním a národní hrdostí. (Ibid., str. 15.)

${ }^{13}$ Ibid.

${ }^{14}$ Ve svém dopise nakladateli posthumního vydání Humových Dialogů o prírozeném náboženství Williamu Strahanovi transponoval Humův prritel Adama Smith obsah svých posledních rozhovorů s Humem do fiktivního dialogu Huma s převozníkem přes řeku Styx Cháronem. V rámci tohoto dialogu, který je improvizován po vzoru Lúkiánových Hovorů záhrobních, uvažuje umírající filosof o tom, jaký důvod by si měl vymyslet, aby mu Cháron povolil odložit o nějaký čas cestu do záhrobí. Nejdřív zjišt'uje, že žádný obvyklý důvod použít nemůže, nebot' udělal vše, co si kdy umínil udělat, a své prátele zanechává v tak dobré situaci, že si stěží lze představit lepší. Posléze připadne na to, že dobrým důvodem odkladu by bylo provedení oprav $\mathrm{v}$ jeho spisech a touha spatřit, jak tyto opravy a změny přijme veřejnost. Na to Cháron odpovídá, že kdyby Hume seznal účinek oněch oprav, zatoužil by uvidět, jak veřejnost reaguje na ještě další opravy a změny a tak dále až donekonečna, takže tento důvod je nepřijatelný, a vyzývá ho, aby nastoupil do člunu. Hume pak uvede poslední důvod: jako 
tvrzení o existenci Boha, třebaže se tím dostává do flagrantního rozporu s celkem své filosofie.

Jestliže si Hume kladl určité meze vexplicitní radikálnosti své kritiky náboženství, pak se to patrně dělo v podobě vnitřního sváru. Kjedné z bojujících stran v jeho nitru patřila kromě onoho nutkání vyvracet absurditu pověr i tendence zavrhnout veškeré autority (o níž také mluví ve zmiňovaném dopisu lékaři); na druhé straně byla touha získat podporu nikoliv pouze několika podobně orientovaných radikálních skeptiků či ateistů, nýbrž těšit se všeobecnému společenskému uznání, které se neobejde bez určité míry konformity. ${ }^{15}$ Jak sám

člověk, který otevíral oči veřejnosti, by rád viděl, kterak se po několika letech projeví vliv jeho učení tím, že zaniknou některé převládající systémy pověr, a žádá o odklad své smrti o těch několik let. Tehdy Cháron ztratí veškerou trpělivost a zakřičí na Huma: “Ty loudající se darebáku, to se nestane ani během mnoha set let! Myslíš si, že ti povolím tak dlouhou dobu? Okamžitě nastup do člunu, ty líný darebáku!" (Srv. The Correspondence of Adam Smith, ed. E. T. Mossner, I. S. Ross, Oxford University Press 1987, str. 219; Smithův dopis Strahanovi byl publikován též in: Essays Moral, Political, and Literary by David Hume, str. 9-15.) Jak zřejmo, myšlenka na nepřemožitelnou moc náboženských pověr vstupuje i do tohoto projevu svrchovaného filosofického humoru stvrzujícího vítězství ironického a sebeironizujícího Humova ducha nad pomíjivostí těla. O nenávistné reakci náboženských kruhů na Smithův výrok, v souladu s nímž se Hume přibližoval „ideji dokonale moudrého a ctnostného člověka tak dalece, jak to snad jen povaha lidské křehkosti dovoluje", viz podrobněji Ján Pavlík, "Adam Smith a teorie spontánního řádu“, in: Adam Smith, Pojednání o podstatě a pưvodu bohatství národi̊, Liberální institut, Praha 2001, str. 903-906.

15 O Humově ctižádostivosti svědčí i jeho pokus etablovat se v pozici profesora morální filosofie na Edinburghské univerzitě $v$ roce 1745 , a sice zejména vzhledem $\mathrm{k}$ tomu, že věděl, že $\mathrm{k}$ povinným úkolům této profesury tehdy patřilo nejen sdělování "pravdy křest'anského náboženství", nýbrž i vyučování tzv. pneumatiky, tj. nauky, která se zabývá bytím a dokonalostí jediného pravdivého boha, přirozeností andělů a lidské duše, jakož i povinnostmi přirozeného náboženství, jimiž jsou rozumní tvorové vázáni vůči Nejvyšší bytosti; v případě, že by některá kniha obsahovala cokoliv, co se jevilo být $\mathrm{v}$ rozporu se Sv. písmem nebo s Vyznáním víry nebo s dobrými mravy, bylo profesorovým úkolem to vyvrátit - aby se tak zabránilo zkažení mládeže omyly či nemorálností. (Srv. M. Alexander Stewart, The Kirk and the Infidel, Lancaster University, 1995; corrected edition, 2001, str. 5.) Otázku, zdali tyto povinnosti byly $\mathrm{v}$ souladu s Humovým naturelem či nikoliv, zde můžeme považovat za zbytečnou. Co se týče průběhu onoho „výběrového řízení", jemuž se Hume podrobil, lze zmínit, že měl mocné podpưrce - patřil k nim John Coutts, který se později stal primátorem Edinburghu, (můžeme-li takto zjednodušeně přeložit termín Lord Provost) a Henry Home (později lord Kames), významný právník a teoretik spontánního řádu); oba byli politicky napojeni na velice vlivného vévodu z Argyllu. Na straně Humových odpůrců nalézáme také významné osobnosti; v první řadě to byl Francis Hutcheson, uznávaný tehdy za největšího britského filosofa, W. Leechman, profesor náboženství (divinity) v Glasgowě, W. Wishart, principál [tj. poradce Synodu (Assembly) Skotské církve v Edinburghu ve věcech církevního práva aj.], dr. (později sir) J. Pringle atd. Wishart při této př́ležitosti vydal protihumovský pamflet (Specimen od the Principles concerning Religion and Morality, etc), načež Henry Home inicioval vydání textu, který obsahoval jak Wishartovy výpady, tak Humovy repliky (tento text je nyní znám pod názvem Dopis jednoho gentlemana svému príteli $v$ Edinburghu). Ve svém pamfletu Wishart vytýkal Humovi skepticismus a ateismus; z Humových odpovědí uved'me myšlenku, že skepticismus se tradičně využíval spíše při obraně náboženství než při útoku na ně. Úsilí Huma a jeho přátel však bylo bezvýsledné, nebot' dřív než městská rada přistoupila k hlasování, vše rozhodl postoj kléru; dvanáct z patnácti ministrư [kteří spolu se staršími (elders) tvoří sbor presbyterů, jenž v presbyteriánské církvi supluje funkci biskupa] se vyslovilo proti Humovi; jejich protihumovské avisamentum bylo podle jednoho ze zainteresovaných současníků motivováno odmítnutím Humových "principư“, kvůli nimž si „zasloužil, aby byl hozen přes palubu“ (behoovd to be dropt). (Srv. ibid., str. 18-19.) Můžeme si snadno domyslet, jakým způsobem ovlivnilo toto 
uvádí, začal s úzkostným čenicháním (scent) po argumentech, které by podpořily obecné mínění; veškerý sklon k názorům druhé strany se pak vloudil proti jeho vůli: pochyby se vkradly (stole in), rozptýlily se, a zase vrátily; když se opět rozptýlily, znovu se vrátily. Právě tento niterný zápas, který charakterizuje Hume jako ustavičný boj neúnavné představivosti proti inklinaci - a možná proti rozumu, ${ }^{16}$ je s největší pravděpodobností tím, co lze označit jako "žhavé jádro“ Humovy osobnosti, budeme-li mít ovšem na mysli, že „neúnavná představivost“ stavěla před Humovu mysl iracionalitu a absurditu náboženství a že jejím protivníkem byl prozíravý rozum, který byl ve službách Humovy potřeby společenského uznání. ${ }^{17}$

Osobnost ovšem lze plně pochopit jen na pozadí doby, v níž působil, resp. jako v kontextu širšího duchovního hnutí, jež reprezentuje. Co týče tohoto druhého zakotvení, musíme v Humově případě vždy zdůrazňovat, že byl (s výjimkou několika málo stanovisek) typickým představitelem skotského osvícenství, které se na rozdíl od antihistorického kontinentálního osvícenství vyznačovalo pochopením dějinnosti a evolučních procesů, v nichž se utvářely společenské instituce. Nicméně možná poněkud přriléhavější bude vřazení Huma mezi velikány tzv. Augustovského věku či století (Augustan Age), jejichž řada začíná klasicizujícími básníky Drydenem a Popem a pokračuje pak přes Swifta a Arbuthnota (tvưrce Johna Bulla) až ke Gibbonovi a Burkovi a dr. Johnsonovi. ${ }^{18}$ Britské myšlení se v Augustovském věku vrací $\mathrm{k}$ renesanci a jí zprostředkovanému klasickému odkazu antiky, zavrhujíc přitom „barokní" epizodu náboženských a revolučních excesů vlastních předešlému století.

Doba, v níž se formovaly základní Humovy filosofické ideje, je co do své duchovní atmosféry jakoby repeticí nálad a postojů typických pro stuartovskou Restauraci,

odmítnutí Humův vztah k etablované církvi a k náboženství vůbec; Hume sám v této souvislosti napsal, že v Edinburghu se proti němu pozvedl „Všeobecný povyk“ (popular clamour). Nicméně skutečnost, že Hume se později spřátelil s jedním ze svých tehdejších odpůrců (Pringlem), je přesvědčivým svědectvím o jeho dobrácké povaze.

${ }^{16}$ Srv. Humův dopis Gilbertovi Elliotovi of Minto (z 10. března 1751) in: Life and Correspondence of David Hume, str. 331-333.

17 Humův vnitřní konflikt byl (alespoň podle toho, co považoval za vhodné říci G. Elliotovi $\mathrm{v}$ citovaném dopise) tak silný, že spálil některé své nepublikované spisy týkající se kritiky náboženství. T. H. Huxley v této souvislosti konstatuje, že Humova sdělení Elliotovi vyvracejí populární představu o Humovi jako bezstarostném skeptikovi, který pochyboval jenom proto, aby pochyboval. (Srv. Srv. Thomas Henry Huxley, Hume, English Men of Letters Series, Harper \& Brothers, New York, 1879, str. 146.)

18 Detmar Doering, Die Wiederkehr der Klugheit, Königshausen und Neumann, Würzburg 1990, str. 39. A. R Humphreys ve svém spise The Augustan World uvádí, že Augustovský věk se vyznačuje chápáním člověka jakožto společenské bytosti, která $\mathrm{v}$ souladu $\mathrm{s}$ božským záměrem spolupracuje na velikém úkolu žít $\mathrm{v}$ obecně rozšířené harmonii a zrríci se hazardu (občanské) války a fanatismu, v němž se zmítalo 17. století. (Cit. in ibid., str. 29.) Je symptomatické, že i sám Hume v eseji „O prostotě a zjemnělosti v písemnictví" poměřuje pokleslý styl literatury v době Claudia a Nerona standardy „vkusu a génia“, jež byly vlastní době Augustově. (Srv. Essays Moral, Political, and Literary by David Hume, str. 243-244.) 
v níž se jako reakce na náboženský fanatismus vlastní „Velké rebelii“ šířil utilitaristický (hobbesovský) racionalismus, amoralismus, cynismus a značně vlažný postoj knáboženství; Britové první poloviny 18. století reagovali podobným způsobem na vlnu náboženské nesnášenlivosti, která souvisela s tzv. Slavnou revolucí (Glorious Revolution) v r. 1688. Co se týče náboženství, již během Restaurace dochází k racionalizaci církevního života; v roce 1729 pak Montesquieu konstatuje, že „náboženství v Anglii neexistuje“ a jako příklad uvádí, že „když jeden člověk v Dolní sněmovně prohlásil: »Věřím tomu jako článku víry!«, začali se všichni smát."19 Jednou $\mathrm{z}$ dalších příčin, jež vedly k uhasínání náboženského fanatismu, byla schopnost elit nejvyspělejších západoevropských národů pohlížet na vlastní kulturu ze stanoviska „nezaujatého pozorovatele“; tato schopnost, kterou, jejíž vývoj v rámci přirozenosti lidského individua artikuloval později Adam Smith ve své Teorii mravních citů, se rozvíjela $\mathrm{v}$ důsledku poznávání radikálně odlišných cizích kultur v souvislosti s ranými formami evropské koloniální expanze. ${ }^{20}$

Z toho však nelze usuzovat, že by v Anglii v době nástupu hanoverské dynastie převládal př́imo ateismus: intelektuální elita stála na pozicích deismu (což je kontinentální termín pro to, co bylo v Anglii označováno jako „přirozené náboženství “); klasickým představitelem deismu byl ještě před Humem Herbert of

${ }^{19}$ André Maurois, ibid., str. 328. Jako kontrast uved'me, že u nás v téže době panovalo koniášovské rekatolizační temno a že ve stejném roce (13. března 1729) došlo bulou papeže Benedikta XIII. Christus Dominus ke kanonizaci Jana Nepomuckého; kanonizační komise uznala Janovi čtyři zázraky: zachování jeho jazyka, jeho naběhnutí a zčervenání, zachránění Rozálie Hodánkové a uzdravení Terezie Veroniky Krebsové.

${ }^{20}$ Francouzskou variantu důsledků onoho „otvírání oken do univerza“ popsal výstižně známý historik Michelet: „Daleké podniky Lawovy, jeho kolonizace, razie podnikané kvůli Mississippi nutí i nejstřízlivější lidi, aby začali myslet na onu druhou polokouli, na ty nezměrné země, ostrovy, jak se tehdy říkalo. V kavárnách, které jsou nyní otvírány po tisících, se hovoří jen o Obou Indiích. Sedmnácté století vidělo Versailles. Osmnácté století vidí zeměkouli. Svět se začal jevit veliký, a Versailles čímsi nepatrným. Naši četní cestovatelé, ba i sami jezuité, kteří odhalovali ohromnou nesmírnost Asie, Mongolska a císařství čínského, dokazovali tím zároveň, že křest’ané představují jen nepatrnou menšinu. Křest'anská problematika začala připadat rovněž jako něco nepatrného. Během jednoho nebo dvou let byla dokonale zapomenuta." Michelet má zde na mysli období těsně po smrti Ludvíka XIV., který se v posledních třiceti létech svého života projevoval jako „jezuita mezi jezuity“, což mělo za následek, že dokud byl král naživu, všichni Francouzi - katolíci, protestanti, libertini i ateisté zachovávali formy náboženského života. Po konstatování, že tato "obrovská fantasmagorie“ náboženského resp. kvázi-náboženského života "splaskla“ a "byla pohozena na půdu“ odkazuje francouzský historik k dílu, v němž metoda "nezaujatého pozorování" evropské kultury nalezla své klasické vyjádření - jde o Montesquieuovy Perské listy; citována je pasáž ze 17. listu, v níž se tvrdí, že se katolictví musí připravit a udělat patřičné pořízení, nebot' mu už valně staletí života nezbývá. (Srv. Jules Michelet, Rekové a rebelové sladké Francie, Odeon, Praha 1974, str. 179-180.) Úpadek křest'anství je ovšem Montesquieuem i Micheletem (jehož lze označit za fanatického antiklerikála) líčen poněkud přehnaně - působení nepř́iliš velkého počtu hlučných pařǐžských literátů a aristokratických libertinů naráželo na setrvačnost křest'anských institucí a tradic, uchovávaných na venkově a $\mathrm{v}$ provinčních městech. Vezmeme-li v úvahu, že v oné době byla Velká Británie v jistém smyslu "pokročilejší" ve filosofické kritice zjeveného náboženství než Francie, pak jako dobrý (a pro naše zkoumání relevantní) doklad hluboké zakořeněnosti křest'anské religiozity v soudobých evropských institucích poslouží výše uvedený výčet povinností profesora morální filosofie na univerzitě v Edinburghu. 
Cherbury; deistou byl také Newton, který se svým ustavením matematické přírodovědy výrazně podílel na dobovém odlivu religiozity, a to nejen v Anglii, nýbrž i ve Francii, kam jeho myšlenky pronikly ve Voltairově zprostředkování. ${ }^{21}$

Osvícenský deismus jakožto racionalizované náboženství zavrhující zjevení úzce souvisel s tendencí k racionalizaci politiky, kterou vyjádřil právě Hume klasickým tvrzením, že „politika může být redukována na vědu“, jež bylo zcela zřejmě orientováno proti horlitelství (enthusiasm) puritánů. ${ }^{22}$

V oblasti finančnictví bují v době Humova mládí neomezené spekulace, které vrcholí v roce 1720 skandálem tzv. "Jihomořské bubliny“ (South Sea Bubble); burzovní propad přivedl tisíce Angličanů na žebráckou hůl a při jeho vyšetřování se zjistilo, že do něj byli zapleteni podplacení ministři včetně kancléře státního pokladu. $\mathrm{O}$ následujícím období vlády sira Roberta Walpola (1721-1742) řekl historik Macaulay, že Walpole „vládl pomocí korupce, protože v jeho době se jinak vládnout nedalo“. ${ }^{23}$ Širúi se opilství, bezuzdná libertinská frivolnost i násilí, jehož se kromě lupičských band beztrestně dopouštějí také př̌íslušníci „zlaté mládeže“ (tzv. mohocks), kteří v Londýně bezdůvodně přepadají chodce. Předmětem všeobecného zájmu se stává jakýsi Jack Sheppard, silniční lupič, o němž John Gay napíše známou hru s názvem Žebrácká opera; jak trefně říká Maurois, hra „líčí nemravnou společnost, která není paní svých banditů a která se jim zbytkem své vlastní krutosti obdivuje“; nelze také nezmínit odpudivý obraz chování anglické aristokracie na začátku 18. století, který podal Victor Hugo ve svém románu Muž, který se směje.

Na druhé straně dlouhá vláda Roberta Walpola, který byl "knížetem míru“, přinesla pozoruhodný hospodářský vzestup Velké Británie; pozitivní roli v něm sehrála i jinak neblahá "Jihomořská bublina“, která (v období svého vzestupu)

${ }^{21}$ Skutečnost, že i deismus je velkým nebezpečím pro zjevené náboženství, postřehl i filosofující pruský král Bedřich Veliký: „Fontenellové a Voltairové, Hobbesové, Collinsové, Shaftesburyové, Bolingbrokové, tito velcí lidé zasadili náboženství smrtelnou ránu. (...) Deismus získal mnoho vyznavačů. Epikureismus se stal zhoubným pro modlářský kult pohanů, deismus nebyl v naší době o nic méně zhoubný pro vidiny judaismu, které převzali naši předkové. Svoboda myšlení, která vládne v Anglii, hodně přispěla k pokroku filosofie." (Cit in: Alexis de Tocqueville, Starý režim a revoluce, Academia, Praha 2003, str. 262.) Podle Tocquevilla neukazuje uvedená pasáž pouze to, že Bedřich považoval v polovině XVIII. za ohnisko neznabožství spíše Anglii než Francii, nýbrž i jeho slepotu vůči politické užitečnosti náboženství, způsobenou tím, že „chyby myšlení jeho učitelů narušily kvality jeho vlastního myšlení". (Ibid.)

22 Viz stejnojmennou Humovu esej in: Essays Moral, Political, and Literary by David Hume, str. 98-109. Program redukce politiky na vědu, který je v rozporu sklasicko-liberálním (smithovským a burkovským) zdůrazňováním prozíravosti (prudence) spočívající v usuzování a jednání podle okolností, činí z Huma předchůdce Comtova pozitivismu a přibližuje jej kontinentálnímu osvícenství. (Srv. D. Doering, ibid., str. 38.)

${ }^{23}$ Samuel Johnson v této souvislosti řekl, že pod vlivem Walpola se whigovství, které se v době revoluce řídilo určitými principy, stalo stranou, jež reprezentovala politiku burzovních spekulantů a náboženství bezvěrců. (Srv. Augustine Birrell, ed., Boswell's Life of Johnson II, Archibald Constable and Co., Westminster 1896, str. 263-264.) Tato Johnsonova kritika mj. objasňuje, proč Hayek odvozoval klasický liberalismus z politiky „starých whigü“. 
přivedla k obchodní činnosti a k obchodnímu myšlení široké masy středních vrstev i aristokracie. Jestliže se v mentalitě Britů v době Humova filosofického zrání projevuje frivolnost, smyslnost a skepticismus, je to způsobeno tím, že stejně jako vyšší francouzské vrstvy žijí Britové v "př́iliš šteastné společnosti““. ${ }^{24}$ Nemělo by se zapomínat, že onu dobu předznamenalo Mandevillovo tvrzení, v souladu s nímž „hlavním principem, který z nás dělá společenské tvory, pevným základem, náplní a oporou všech živností je bez výjimky špatnost“; Mandevillův cynismus nachází teprve později svou korekci v teorii mravního citu, jejímiž hlavními reprezentanty jsou sám Hume a posléze Adam Smith.

Pokusíme-li se chápat Humovu filosofii jako artikulaci dobové mentality či tzv. Zeitgeistu, pak je zřejmé, že musíme zcela jednoznačně zamítnout mínění, že by vyjadřovala dobovou zkaženost a frivolnost. Hume (stejně jako Smith) reflektoval růst a rozvoj svobodné společnosti založené na tržním řádu a na respektování katallaktických pravidel, která ho umožňují, a právě z této reflexe vyvodil své optimistické pojetí člověka, v souladu s nímž člověk jakožto bytost vybavená univerzálním citem sympatie je ve své přirozenosti dobrý. Př́činu existence společenského zla přitom Hume (poněkud zjednodušeně) spatřoval v „přežitcích minulosti“" tj. zejména v neblahém dědictví náboženského fanatismu, jenž tím, že vede lidi ke vzájemné nenávisti, působí proti lidské přirozenosti. ${ }^{25}$ Jeho raná filosofie vyjadřuje naději, že antireligiózní působení skeptického rozumu uvolní prostor pro spontaneitu mravního cítění; přímo v ní prosvítá přesvědčení, že když se necháme vést rozumem (hlavně $\mathrm{v}$ jeho funkci bořitele náboženských mýtů, ale také v politice), bude zanedlouho všechno špatné již za námi.

Hume ovšem nepočítal s tím, že tzv. citová revoluce (kterou svou naukou o mravním citu pomáhal připravit) povede i k rozššřcní reformních snah náboženských, které, jak říká Churchill, prolomily „pyšný krunýř Věku rozumu“. John Wesley sice založil své reformní hnutí, jemuž se začalo posměšně říkat

\footnotetext{
${ }^{24}$ Srv. André Maurois, Dějiny Anglie, str. 328. S tímto náhledem liberálně orientovaného Mauroise se podivně shoduje i kvazi-marxistický pohled Nejedlého, který píše, že "Hume není filosof mladé, rozvíjející se teprve společnosti, jak tomu je např. u Locka. Hume je typický filosof již společnosti u cíle, mocné, hotové" a dodává, že kontinentální recepce Huma na konci 19. století (kam zařazuje i jeho recepci Masarykem) odpovídá skutečnosti, že v tomto období došlo k „uzrání“ buržoazie i na evropském kontinentu. (Zdeněk Nejedlý, ibid., str. 122.)

${ }^{25}$ To ovšem neznamená, že Hume nebyl citlivý na negativní rysy Walpolovy vlády; oceňuje sice, že během ní "obchod vzkvétal", avšak poukazuje i na to, že "svoboda upadala" a že "učenost byla zruinována"; vyvozuje z toho závěr, že jako člověk Walpola miluje, ale jako vědec jej nenávidí a jako Brit si přeje jeho pád. (Srv. The Philosophical Works of David Hume, Vol. III, Edinburgh 1826, str. 30.) Jak uvádí James Orr (David Hume and His Influence on Theology and Philosophy, T \& T. Clark, Edinburgh 1903, str. 222), nejautentičtějším důkazem Humova interesu o svobodu je jeho pasáž z eseje „O svobodě tisku“, v níž se Hume vyslovuje, že rostoucí zkušeností lidstva bylo prokázáno, že lidé nejsou tak nebezpečné obludy, jak se to prezentovalo, a že je v každém ohledu lepší je usměrňovat (guide them) jako racionální bytosti, než je vodit či pohánět (lead or drive) jako tupá zvířata (brute beasts). (Srv. The Philosophical Works of David Hume, Vol. III, str. 12.)
} 
"metodismus" a jež chápalo pravou víru jako citový prožitek vytržení a splynutí s Bohem, již v roce 1726, avšak citově obrozená religiozita se obecněji rozšiřila až ve druhé polovině 18. století (na základě toho, že i ostatní církve - pokud nechtěly podlehnout $\mathrm{v}$ konkurenčním boji o duše věřících - se dopracovaly k podobné intenzitě náboženské vroucnosti). ${ }^{26}$ Zdá se, že osvícenec Hume nechápal zcela důsledně, že potřeba vztahu k transcendentnu je nezrušitelným rysem lidské přirozenosti a že se může realizovat i v modu credo quia absurdum est. ${ }^{27} \mathrm{Na}$ rozdíl od svého současníka Voltaira, který nahlédl, že člověk nemůže žít bez nadšení a že strnulost nudy se nutně střídá s "křečí nepokoje“, reaguje umírající Hume (v citovaném fiktivním dialogu s Chárónem) na obnovení náboženské vroucnosti tím, že přiznává „pověrám“ nezdolnou sílu. Neuvědomuje si, že od doby, kdy oprávněně kritizoval propojení tehdy úpadkového náboženství s politikou, se situace změnila, a že citově zvroucnělé náboženství, oddělené (de facto, i když ne de iure) od státu a přenesené do soukromé sféry, může vést $\mathrm{k}$ velice pozitivním důsledkům (jakým bylo např. zrušení otroctví ve Spojeném království v r. 1833). ${ }^{28}$

${ }^{26}$ V roce 1790 mohl Burke jménem svým i jménem vládnoucích britských elit s velkou mírou oprávnění prohlásit, že „víme a - což je důležitější - vnitřně cítíme, že náboženství je základem občanské společnosti, zdrojem všeho dobra a vší útěchy. V Anglii jsme o tom přesvědčeni natolik, že žádná rez pověry, jíž mohla v průběhu věků pokrýt náboženství nahromaděná pošetilost lidské mysli, není pro devadesát devět Angličanů ze sta tak hrozná, aby před ním dali přednost bezbožnosti. (...) Víme - a jsme na to pyšní -, že člověk je svou přirozeností náboženský tvor, že ateismus nejen není ve shodě $\mathrm{s}$ naším rozumem, ale že se též příćí našim instinktům a nemůže zvítězit na dlouho. (...) Angličané nepovažují církev pouze za vhodný prostředek, ale za esenciální prvek státu; nepovažují ji za věc cizorodou a oddělitelnou, něco přidaného kvůli pohodlí, co je možno si bud' podržet, nebo odložit podle toho, jaké jsou právě představy o tom, co je výhodné. Považují ji za základ celého svého zř́zení, s nímž - a s každou jeho částí - je spojena v nerozlučitelnou jednotu. (...) Mužové Anglie myslím tím přední, vynikající osobnosti -, jejichž moudrost (je-li jaká) je otevřená a př́má, by se museli hanbit, jako by provedli nějaký hloupý, podvodný úskok, kdyby měli vyznávat nějaké náboženství jen formálně, a přitom by jím zjevně pohrdali." (Edmund Burke, Úvahy o revoluci ve Francii, Centrum pro studium demokracie a kultury, Praha 1997, str. 99, 107-108, 109.)

${ }^{27}$ Mauroisovo tvrzení, že „nuda a touha po vzrušení vedly v Anglii stejně jako ve Francii po padesáti letech skepticismu a egoismu k citové revoluci“, je jen (duchaplnou) simplifikací, která nepostihuje př́činy vzniku citové obrody náboženství, jež byla integrální součástí „citové revoluce“ v Anglii.

28 Tocqueville vidí ve znovuvzkřrššení náboženského ducha ve Velké Británii výron politické prozíravosti britských elit, opírající se o promýšlení zkušeností z revolucí XVII. století: „Po celé XVIII. století mělo bezvěrectví $\mathrm{v}$ Anglii slavné představitele. $\mathrm{K}$ bezvěrectví se přikláněli významní spisovatelé a hlubocí myslitelé. Nikdy mu však nedokázali otevř́it cestu k triumfu jako ve Francii, protože všichni, kdo se měli čeho obávat $v$ revolucích, spěchali pro pomoc $\mathrm{k}$ zavedené víře. Dokonce i ti z nich, kteří byli nejvíce propojeni s francouzskou společností své doby a učení našich filosofů nepovažovali za nesprávné, je odmítali jako nebezpečné. (...)Ač bylo ustavení anglikánské církve chybou a vzdor všemožným zlořádům, kterými se to $\mathrm{v}$ ní hemžilo, přečkala tento náraz vítězně. Spisovatelé a řečníci vycházeli z jejích řad a pouštěli se se zápalem do obrany křest'anství. Teorie, které byly křestanství nepřátelské, byly diskutovány a vyvraceny, a nakonec odmítnuty úsilím samotné společnosti bez zásahu vlády." (Alexis de Tocqueville, Starý režim a revoluce, str. 185.) V zásadě totéž tvrdí Tocqueville i o francouzské společnosti své doby: „Který Francouz by se dnes opovážil psát knihy jako Diderot nebo Helvétius? Kdo by je chtěl číst? (...) Neúplná zkušenost, kterou jsme získali za šedesát let ve veřejném životě, postačila $\mathrm{k}$ tomu, aby nám znechutila tuto nebezpečnou literaturu. 
$\mathrm{Na}$ závěr této úvodní kapitolky uved'me Hegelovo vymezení skepticismu z Fenomenologie ducha, které je velice relevantní pro pochopení vztahu mezi Humovou skepsí a náboženstvím. Skepticismus i jeho předchůdce, jímž je stoicismus, nepatři podle Hegela do filosofie ve vlastním slova smyslu; jde jen o podoby duchovní emancipace raba zotročeného pánem. Zatímco stoicismus, který hlásá pouze vnitřní svobodu raba, aniž by přitom vyjadřoval snahu o praktické přetvoření skutečností, je jen (duchovní) kopií postoje nečinného pána, nabývá ve skepticismu myšlenkovou podobu životní činnost raba, spočívající v tom, že ničí danou formu předmětnosti (aby do ní mohl vtisknout svůj účel). Skepse tudíž provádí důkaz nicoty předem daných, předpokládaných pravd a vztahů. Jak říká Hegel, "skeptické sebevědomí zakouší tedy v proměně všeho toho, co pro ně chce být pevným, svou vlastní svobodu jako sobě jím samým danou a udržovanou“ .29 Jde ovšem opět jen o vnitřní svobodu, nebot' v důsledku toho, že skeptické vědomí přivádí do konfliktu protikladná tvrzení, a tím rozkládá vše, co je stabilní, dospívá jen ke svobodě v modu lhostejnosti ke všemu. ${ }^{30}$ Zároveň však platí, že pokud skeptické vědomí relativizuje vše, musí relativizovat i sebe sama; musí se tedy učinit nerovným pravdě, absolutnu, dívat se na sebe jako na zvířecí, zmatené, ustavičně proměnlivé vědomí. Výsledek tohoto sebevztažení tkví v tom, že skeptické vědomí, „místo aby bylo vědomím soběrovným, jest pouze naprosto nahodilým zmatkem, závratí nepořádku ustavičně se vytvářejícího. Tím je pro sebe; nebot' samo tento zmatek, který se sám uvádí v pohyb, udržuje a vytváří. Proto se k němu též přiznává, vyznává, že je zcela nahodilé, jednotlivé vědomí (...) Ale právě tak, jak pro sebe tímto způsobem platí za jednotlivý, nahodilý a vskutku zvířecí život a ztracené sebevědomí, činí se naopak opět také všeobecným soběrovným životem; nebot' jest zápornost všeho jednotlivého...“31

Skeptické vědomí, které je z tohoto hlediska dvojím (rozštěpeným) vědomím, se podle Hegela překonává tím, že podvojnost relativního a absolutního (svobodného) se sjednotí do jednoho vědomí; na tomto novém stupni vědomí je relativní i absolutní dáno ve svém rozporném vztahu. Tento vztah, jímž jsou obě určení k sobě

Vidíte sami, jak úcta k náboženství znovu postupně nabyla vlivu v různých tříách národa, tak jak každá z nich nabývala této zkušenosti v tvrdé škole revolucí." (Ibid.)

${ }^{29}$ G. W. F. Hegel, Fenomenologie ducha, NČSAV, Praha 1960, str. 166.

30 Tomuto Hegelovu vymezení skeptického př́stupu dobře odpovídá postup Humova skeptického myšlení, o němž Hume sám říká, že při slabosti lidského rozumu a při neodolatelné nakažlivosti (náboženského) mínění, které způsobují, že se úmyslná pochybnost dá stěží udržet, je třeba stavět jeden druh pověry proti druhému a dohnat je ke srážce; my se pak, pokračuje Hume, „za jejich zběsilosti a boje št́astně uchýlíme do tichých, ač temných končin filosofie“. [David Hume, Přrirozené dějiny náboženství a Rozmluvy o náboženství prírozeném, Jan Laichter, Praha 1900 (dále PR), str. 80.)] Dodejme, že Humovo pojetí slabosti rozumu, který zvítězí nad silou iracionálních pověr jen tím, že je (perfidně) navzájem staví proti sobě, je jedním z inspiračních zdrojů Hegelova slavného konceptu „1sti rozumu".

${ }^{31}$ G. W. F. Hegel, ibid. 
připoutaná, znamená, že onen nový stupeň vědomí je bolest a citová vázanost k absolutnu. Hegel jej označuje termínem "nešt’astné vědomí“, za nímž se skrývá vědomí charakteristické pro prvotní křestanství: Křest'an na jedné straně tvrdí, že „svět tone ve zlu“, na druhé straně prohlašuje svět za dílo božích rukou; také sám o sobě tvrdí, že je hř́išný a zároveň že je stvořen k obrazu Božímu. Právě tuto

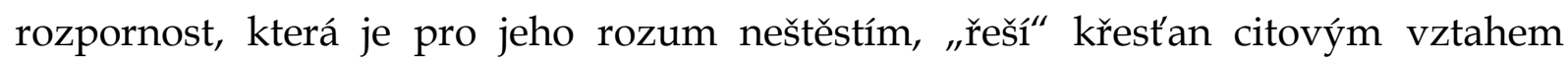
$\mathrm{k}$ absolutnu.

Je zřejmé, že Hegelem popsanou strukturu přechodu od antického skepticismu k prvotnímu křest'anství lze mutatis mutandis přenést i na myšlenkové dění, které vedlo od humovského (resp. obecněji osvícenského) skepticismu k citově obrozenému křest'anství (jehož iniciátor Wesley se inspiroval učením Moravských bratří, kteří, jak známo, se též vraceli k myšlenkovým a prožitkovým zdrojům prvotního křest́anství); na další relevantní rysy Hegelovy koncepce pro humovská zkoumání upozorníme níže.

\section{Teze}

I. Smyslem a cílem veškerého Humova filosofování (zejména jeho popření ontologického statusu kategorií substance a kauzality a jeho teorie mravních citů) je připravit půdu pro skeptickou destrukci veškerých tvrzení týkajících se existence a přirozenosti Boží a pro zdůvodnění pojetí, v souladu s nímž může člověk žít mravně bezúhonným životem i bez jakékoliv opory v náboženském transcendentnu (v tomto kontextu Hume dokonce a fortiori argumentuje, že náboženství může představovat závažnou překážkou uplatňování přirozené mravnosti).

II. Všechny silně nekonsistentní momenty Humovy filosofie jsou sjednoceny (obvykle perfidně utajovaným) účelem, jímž je vyvrátit náboženství z kořene; právě z onoho vrcholného bodu "syntézy“ lze uchopit jejich smysl a - zároveň také jinak neuchopitelnou jednotu Humovy filosofie.

III. Popření ontologického statutu kategorie substance (které nachází svůj výraz v její psychologizaci do podoby pouhé habituální víry), traktované v kontextu řešení problematiky teleologického do̊kazu Boží existence, rezultuje u Huma (takřka s železnou logikou) v anticipační nástin fundamentálních myšlenek evolučního přístupu a teorie samoorganizace, které s velkou pravděpodobností přímo ovlivnil pojetí Charlese Darwina.

\section{Hume vs náboženství}


Tvrzení, že (skoro) všechna Humova filosofémata vyúst'ují explicitně nebo implicitně v kritice náboženství, je potvrzeno mj. jeho metodickou zásadou, kterou převzal od starověkých autorů a která stanovuje, že ti, kdo se obírají filosofií, měli by se nejprve naučit logice, potom etice, na to pak fyzice a nakonec teprve přirozenosti bohů. To, že je filosofická nauka o Bohu řazena jako poslední v pořadí, neznamená její nevýznamnost, nýbrž to, že je nejhlubší a nejnepřístupnější ze všech; lze k ní přistoupit teprve když se duch obohatí všemi ostatním vědami; je tudíž syntézou všech filosofických věd. ${ }^{32}$

Podívejme se nejdřív na Humovy výroky, jež se zdají odporovat výše vytčeným tezím. Jak již víme, i v nejskeptičtějším ze všech svých spisů, jímž jsou posthumní Dialogy o prirozeném náboženství, nás Hume ujištuje o tom, že existence Boží je mimo vší pochybnost. ${ }^{33}$ Toto tvrzení je ovšem v nepřekonatelném rozporu s jeho tvrzením, že „je pro nás nemožné myslit cokoliv, co jsme dříve nepocit'ovali svými vnějšími nebo vnitřními smysly“34 i stvrzením, že „nemáme žádnou zkušenost týkající se počátku světů“. Jinými slovy, jelikož veškeré poznání podle Huma pochází ze zkušenosti a všechny naše ideje jsou pouze kopiemi impresí (daných ve vnějším nebo vnitřním vnímání), pak Bůh, který se jakožto nadsmyslná či ryze duchovní bytost $\mathrm{v}$ naší zkušenosti ex definitione neukazuje, nejenže neexistuje, nýbrž není vůbec myslitelný (chápeme-li pod Humovým pojmem „myslit“ myšlení v silném smyslu neboli myšlení korektní). K tomu, aby Hume vyvrátil existenci Boží, navíc stačí, aby se odvolal na své popření ontologického statusu příčinnosti a substanciality, tj. na koncepci, podle níž kauzalita i substance nejsou nijak přitomně ve zkušenostním východisku našeho poznání a mají status pouhých habitualit našeho myšlení, kterými v naivním (předhumovském) postoji onen zkušenostní základ našeho myšlení nekorektně podkládáme či usouvztažňujeme. Jestliže se tedy substance jakožto nezjevný sebeidentický základ jakéhokoliv komplexu počitků (impresí) naší mysli redukuje na víru (belief) založenou na zvyku (čili na ryze subjektivní sedlinu zpo̊sobenou jeho mnohonásobným výskytem), což znamená, že její existence mimo mysl je zcela vyloučena, pak nemůže být Bůh substancí; ze stejných důvodů nemůže být ani přičinou, tím méně pak spinozovskou př́ičinou sebe sama. Nemůže být ani osobou, nebot' Humova kritika substanciality postihuje i nezjevný sebeidentický základ prožitků vnitřního vnímání, který se označuje jako duše, resp. jako res či substantia cogitans. Nemůže být dokonce subjektem, protože Hume zamítá působnost aktu sebeuvědomění, který by vztahoval mnohotvárný (a

\footnotetext{
32 Srv. $P R$, str. 86.

33 Tvrzení o existenci Boha je podle Humova vyjádření pravda očividná, jistá, samozřejmá, „již uznávaly věky nejnevědomějši” (sic!) a pro niž „duchové nejdůmyslnější pokoušeli se ve své ctižádosti uvést nových důkazů a důvodů“; tato pravda je prý "základem všeho našeho mravního doufání, nejbezpečnější podstavou mravnosti, nejpevnější podporou společnosti a jedinou zásadou, již bychom ani na okamžik neměli pouštět z mysli při všem přemýšlení a uvažování svém“. ( $P R$, str. 84-85.)

${ }^{34}$ David Hume, Zkoumání o lidském rozumu, Svoboda, Praha 1996 (dále ZR), str. 96.
} 
plynoucí) obsah naší mysli vždy k témuž sebeidentickému Já, ${ }^{35}$ podle Huma Já neexistuje, protože nemáme žádnou jeho impresi. Hume nepřijímá ani koncept Boha jakožto mimočasového ducha, strnule trvajícího $\mathrm{v}$,jediném, jednoduchém, dokonalém stavu“ , nebot' duch, jehož „úkony a city a představy nejsou nijak rozdílné a posloupné (...) jest duchem, nemajícím žádného myšlení, rozumu, žádné vưle, žádného citu, žádné lásky ani záští, nebo zkrátka, není vůbec duchem“. ${ }^{36}$ Když dále Hume probírá charakteristiku Boha jakožto bytosti nutně existující, uvádí argument, že cokoliv, co si představujeme jako jsoucí, si můžeme představit též jako nejsoucí, a že není žádné bytosti, jejíz nebytí by v sobě obsahovalo rozpor; závěr tohoto vyvracení ontologického důkazu Boží existence tkví v tvrzení, že slova "nutné bytí“ nemají smysl neboli, což je totéž, nemají důsledný smysl. ${ }^{37}$ Bůh tedy opravdu nemůže být ničím myslitelným; s použitím modernější terminologie můžeme říci, že podle Huma Boha lze mínit, nikoliv však myslet v silném smyslu, tj. korektně a bezrozporně.

Otázka, proč Hume deklaruje existenci Boha, byla již zodpovězena výše - je to jeho způsob, jak zajistit, aby se z něj nestal společenský vyděděnec a zároveň naplnit heslo sapienti sat. Oněm moudrým bylo ovšem vše jasné: jeden z nich, Thomas Henry Huxley, poznamenal, že pokud se vůbec někdy Hume zdá být neupřímný, je to tehdy, když chce potupit teology tím, že staví na odiv sarkastickou úctu vưči nim. ${ }^{38}$ Huxley dále říká, že "Humův theismus se rozplývá v dialektické řece, až z něj nezůstane nic jiného než slovní obal (sack), v němž byl obsažen“. 39

\footnotetext{
${ }^{35}$ Hume ujišt'uje všechny své spolubližní, že nejsou ničím jiným než svazkem nebo souhrnem různých percepcí (bundle or collection of different perceptions), které následují po sobě s nepředstavitelnou rychlostí a jsou ve věčném toku a pohybu. (Srv. The Philosophical Works of David Hume, Vol. I, Edinburgh 1826, str. 821.) Poté, co empiriokriticisté (pozitivisté druhé generace) Mach a Avenarius recipovali koncem 19. století tuto Humovu koncepci, propagovali jimi inspirovaní vídeňští impresionisté (k nimž patř̌il též náš německy píšící krajan Robert Musil) heslo „Já nelze zachránit!“ (Das Ich ist unrettbar!).

36 Srv. $P R$, str. 122-123.

${ }^{37}$ Srv. $P R$, str. 158-159.

${ }^{38}$ Srv. T. H. Huxley, Hume, str. 138. Do očí bijíí sarkasmus nebyl vlastní jen Humovi; použil ho např. též Shaftesbury, když v článku, v němž vyvracel všechny články křest'anské víry, mluvil o své pravověrnosti a podřízenosti pravé církvi, tak jak byla ustavena zákonem; také Gibbonova ironie byla př́slovečná. (Srv. James Orr, ibid., str. 196.) Stojí za zmínku, že k Humovu perfidnímu sarkasmu patří i to, že v dopise G. Elliotovi označuje za hlavního hrdinu svých Dialogů o přirozeném náboženství nikoliv ateistu a protodarwinistu Filóna, nýbrž bezbarvého deistu Kleantha; Filón přitom ve své argumentaci jednak vychází ze známých Humových tezí ohledně kauzality a charakteru mysli, jednak v každé diskusi vítězí nad svým oponentem. (Srv. ibid., str. 201.) Z toho ovšem plyne, že ani v dopise príteli se Hume neobešel bez jistého stupně perfidní sebestylizace.

${ }^{39}$ T. H. Huxley, ibid., str. 144-145. Dodejme pouze, že to, co Huxley označuje jako "theismus", znamená v naší terminologii "deismus" - o theismu jakožto viřre v osobního Boha, který zasahuje do dění ve světě i poté, co jej stvořil, nelze u Huma vůbec mluvit. V této souvislosti zmiňme, že podle Orra dopívá Hume v závěrečných partiích Dialogů o přirozeném náboženství přímo k ateismu. (Srv. James Orr, ibid., str. 208.)
} 
Dalším Humovým výrokem, který mnozí jeho interpreti berou vážně, ${ }^{40}$ je jeho formulace teleologického argumentu ve prospěch existence Boha. ${ }^{41}$ Hume však hned na následující stránce upřesňuje, že „všeobecná náchylnost, věřit v moc neviditelnou, rozumnou, je ne-li původním pudem, tedy aspoň všeobecným souzjevem přirozenosti lidské“" což znamená, že podobně jako v případě kauzality a teleologie je autor účelného uspořádání světa převeden na produkt pouhého antropologickopsychologického sklonu. ${ }^{42}$ Hume tak skoro doslova předjímá Kanta, který v Kritice soudnosti stanovuje, že existuje všeobecná a nutná potřeba traktovat apriorně přírodu tak, jakoby byla produktem božského rozumu; Kant přitom zdůrazňuje, že saturace této potřeby není poznáním - a tedy ani teleologickým důkazem Boží existence.

Jinde v souvislosti s teleologickým argumentem Hume uvádí, že pokud je základ přirozené teologie obsažen v tvrzení, že příčina nebo př́ičiny řádu ve vesmíru asi jeví jakousi vzdálenou analogii s lidským rozumem, pak vzniká dojem „jakési truchlivosti“ z předmětu tohoto tvrzení a ,jakési opovržení k lidskému rozumu, že nedovede podat uspokojivějšího rozřešení v otázce tak nadobyčejné a vážné“. ${ }^{43}$

Vyvrací-li Hume myšlenku existence Boha jen tímto perfidně-implicitním způsobem, pak je zcela explicitní, jedná-li se o představu Boha jakožto bytosti

40 Např. Felix Müller (David Humes Stellung zum Deismus, Buchdruckerei Robert Noske, Borna-Leipzig 1906, str. 37-38) tvrdí, že v otázce teleologického argumentu zastává Hume střední pozici mezi jeho obhájci (Aristoteles, Anaxagorás) a těmi, kdož jej vyvraceli (Descartes a Spinoza).

41 Celé znění Humova teleologického argumentu je následující: „Ač hloupost lidí barbarských a nevzdělaných jest tak veliká, že nevidí svrchovaného původce ve všednějších dílech přírody, jež jsou jim tak velice povědoma, přece zdá se téměř nemožným, že by člověk zdravého rozumu mohl zamítnout tu myšlenku, když mu byla vnuknuta. Účel, úmysl, záměr jest patrný ve všem; a když chápavost naše jest tak dalece rozšířena, že uvažujeme o prvém povstání této viditelné soustavy, musíme osvojit si s nejpevněǰ̌ím přesvědčením ideu nějaké rozumné př́ičiny, nějakého rozumného původce. I odpory [v originálu contrarieties, tj. rozpory či protivenství] v přírodě, všude se ukazujíce, stávají se důkazy jakéhosi důsledného plánu a stanoví jeden jediný úmysl neboli záměr, bud’ si on jakkoli nevysvětlitelný a nepochopitelný.“ (PR, str. 77.)

42 Humovi vlastní opatrná prozíravost jej ovšem vede k dodatku, že zmíněný „souzjev“ lidské přirozenosti lze pokládat „za jakousi známku nebo pečet', již božský tvưrce vtiskl svému dílu“. (PR, str. 78-79.)

${ }^{43}$ Srv. PR, str. 208. Podle Husserla se v Humově Traktátu „mění ve fikci svět vůbec, příroda, universum identických těles a svět identických osob a tím i objektivní věda, poznávající svět v jeho objektivní pravdě. Důsledně musíme říci, že rozum, poznání, i poznání pravých hodnot a čistých ideálů jakéhokoli druhu včetně ideálů etických - není nic jiného než fikce. Je to tedy vskutku krach objektivního poznání. Hume končí vlastně v solipsismu. Jak mohou totiž závěry z dat na data překročit imanentní sféru?" (Edmund Husserl, Krize evropských věd a transcendentální fenomenologie, Academia, Praha 1972, str. 110.) V souladu s touto př́ísnou, leč zároveň zcela přesnou charakteristikou Humova skepticismu může být Humův koncept teleologicky působícího Boha útvarem nalézajícím se jedině v imanenci v naší mysli; pokud tento útvar chápeme jako nutný „souzjev“ lidské přirozenosti, můžeme nanejvýš připustit, že má apriorní povahu. Husserl pak dále (zcela oprávněně) vytýká Humovi absenci transcendentální reflexe: „Hume ... neřekl... ani slova o tom, jak se to má pak $\mathrm{s}$ rozumem, s Humovým rozumem, který zdůvodnil tuto teorii jako pravdu..." Z této výtky mj. plyne, že Hume nedisponuje žádnými pojmovými prostředky, které by mu umožnily dokázat, že onen koncept Boha se nutně vyskytuje ve všech lidských myslích. 
přesahující jím stvořený svět a realizující (formou odměňování dobrých a trestání zlých) distributivní spravedlnost. Na začátku svého kritického tažení (jakoby) přijímá teleologický argument (založený na představě, že v řádu př́rody se „setkáváme s takovými známkami inteligence a uspořádání, že byste považovali za extravagantní označit za jeho příčinu bud'to náhodu, nebo slepou a neřízenou materiální sílu“) a opět ujišt'uje, že Boží existenci nijak nezpochybňuje. Uplatňuje však zároveň myšlenku, že pokud je svět ztělesněním Božího účelu, musel Bůh tento účel uvést ve skutečnost jedině kauzálním působením. Pak ovšem musí platit, že stejně jako je tomu u "pozemských“ prř́čin - nesmíme při vyvozování (neznámé) příčiny ze (známého) účinku do ní vkládat víc, než je obsaženo v účinku; pokud tak přesto učiníme, dostáváme se do sféry dohadů a libovůle. Z toho plyne, že když připustíme, že Bůh je příčinou existence a řádu vesmíru, musí mu náležet právě tolik moci, inteligence a dobré vůle, kolik se jeví v jeho díle. ${ }^{44}$ Když naopak usuzujeme, že Bůh jakožto uskutečňovatel svrchované distributivní spravedlnosti odměňuje dobré a trestá špatné ještě ve větší míře, než se tak děje v jím stvořeném světě, pak jde o chybný úsudek. Hume pak dochází k závěru, že uskutečňují-li lidé ve světě distributivní spravedlnost, pak je tato spravedlnost již dostatečně naplněna. Je zřejmé, že Hume jakožto liberál a zastánce komutativní spravedlnosti (kterou chápe v podobě pravidel garantujících stabilitu soukromého vlastnictví, jeho přenos na základě dohody a plnění smluv a slibů) dobře ví, že vkládat do Boha svrchovanou distributivní spravedlnost, jejíž míra přesahuje míru té, která se uplatňuje ve světě, by znamenalo vytýkat světu, že je v něm nedostatek distributivní spravedlnosti, z čehož by pak nutně plynul nábožensko-politický požadavek vzestupu k Bohu formou snahy o zvětšení míry distributivní spravedlnosti zde ve světě.

I přes tento - z liberálního hlediska potěšující - Humův závěr bychom neměli pouštět ze zřetele, že Hume v této argumentaci bezstarostně pracuje s ontologickým pojetím kauzality, které jedině umožňuje formulovat tvrzení o tom, že v přičině nesmí být víc než v účinku - při redukci přičinného vztahu na pouhé post hoc totiž může být $\mathrm{v}$ "přričině“ cokoliv. ${ }^{45}$ (Kant, který si je také vědom, že distributivní spravedlnost nelze aplikovat na tržní řád, avšak na rozdíl od Huma ví, že naděje lidí na její dokonalé naplnění je nezrušitelná, činí z této naděje jeden z postulátů praktického rozumu, tj. jeden z apriorních předpokladů mravního jednání, jemuž ovšem neodpovídá nic, co by transcendentně existovalo. $)^{46}$

\footnotetext{
44 Humova opatrná prozíravost se v této pasáži projevuje tím, že místo o křest'anském Bohu mluví raději o bozích. (Srv. David Hume, Zkoumání o lidském rozumu, str. 188-189.)

${ }^{45}$ Hume navíc tvrdí, že svět je „účinek jedinečný a s ničím nesrovnatelný“ (an effect quite singular and unparalleled), tj. účinek, který je vůči regulárním, opakujícím se kauzálním vztahům zcela výjimečný. (Srv. ZR, str. 202.)

${ }^{46}$ Myšlenka svrchované distributivní spravedlnosti připadá Humovi absurdní i proto, že implikuje, že člověk by byl za konečnou (pozemskou) zásluhu odměněn nekonečným štěstím (na nebesích) a za rovněž konečné prohřešky spáchané na tomto světě by se mu dostalo nekonečného utrpení (v pekle).
} 
Vyvrací-li Hume pojetí boha jakožto garanta a naplňovatele nadzemské distributivní spravedlnosti i za cenu, že se ocitá v rozporu se svým vlastním chápáním kauzality, pak je tomu nejinak i v případě jeho vyvracení existence zázraků, které pokud nejsou přímo "živoucím nervem“ všech náboženství (Feuerbach), jsou alespoň „nejmilejším dítětem víry“ (Goethe). ${ }^{47}$ Hlavní Humův argument má jakoby apriorní povahu: pokud je skutečné to, co je potvrzováno uniformní zkušeností lidstva (čili mnohonásobně opakovanou zkušeností dostupnou všem lidem), pak zázrak, který ex definitione není potvrzován touto uniformní zkušeností, nemůže být skutečný. V konkrétnější podobě Hume argumentuje, že zázrak je porušením (violation) přrírodních zákonů, které ustavila "pevná a nezměnitelná" (firm and unalterable) zkušenost, a tudíž je do̊kaz (proof) proti zázraku z povahy věci tak úplný, jak si jen u argumentu ze zkušenosti lze představit. ${ }^{48}$ Tento „důkaz", o němž Hume prohlásil, že "přetrvá věky“, je stěží něčím lepším než jen rozvinutým sofismatem. ${ }^{49}$ Humovo zrušení ontologického statusu kauzality a její redukce na subjektivní víru založenou na zvyku totiž zcela destruuje ideu přírodního zákona jakožto nutné souvislosti, která se za přislušných podmínek uplatňuje vždy a všude. Zjednodušeně řečeno, jestliže jsme mnohokrát zakusili, že slunce vyšlo na východě, pak Humovo zrušení ontologické kauzální nutnosti znamená, že při nutně omezeném počtu dosavadních pozorování tohoto děje není vyloučeno, že zítra vyjde slunce na západě; je to pouze málo pravděpodobné. 50 Stejně tak málo pravděpodobný, leč nikoliv zcela vyloučený je tedy i zázrak; chtěli-li by někdo hledat způsob, jak podat kvalifikovanou fundaci možnosti zázraků, nenašel by patrně nic

(Srv. T. H. Huxley, Hume, str. 76.) Z Humových vyjádření týkajících se první příčiny veškerenstva lze celkově vyvodit, že tato př́čina (pokud ji svým perfidním způsobem připouští) je naprosto indiferentní vưči lidským myšlenkám o ctnostech a neřestech. (Srv. John P. Wright, Hume's Treatise of Human Nature, Cambridge University Press, Cambridge 2009, str. 257.) Wright poukazuje i na to, že ve svém Traktátu Hume nikde nemluví o dobrotě Boží a že jenom do apendixu ke jeho 3 . knize vkládá poznámku, v níž nominálně akceptuje teleologický argument. (Ibid., str. 256.) Tím je na pravou míru uveden i výše citovaný Humův perfidně hyperdevótní výrok, že myšlenku existence Boha bychom „,neměli ani na okamžik pouštět $\mathrm{z}$ mysli atd.“ Zmiňme ještě, že nepř́jemnou problematiku teodiceje řeší Hume opět vysoce perfidním tvrzením, že všechny filosofické pokusy očistit Boha od podezření, že je původcem hříchu, doposud selhaly, a že je tudíž třeba, aby si přirozený rozum uvědomil svoji nezpůsobilost $\mathrm{v}$ tomto směru a raději se věnoval zkoumání běžného života ve společenském světě. (Srv. ZR, str. 146.)

${ }_{47}$ Srv. Felix Müller, ibid., str. 19.

${ }^{48}$ Srv. ZR, str. 159.

${ }^{49}$ James Orr, ibid., str. 210.

${ }^{50}$ Hume explicitně tvrdí, že „každý důkaz nutnosti př́činy je klamný a sofistický" a že "neexistuje žádná absolutní či metafyzická nutnost, aby každý počátek existence měl (k dispozici) takový objekt, jakým je př́rcina“. (Srv. The Philosophical Works of David Hume, Vol. I, str. 111, 227.) Jak uvádí znamenitý historik filosofie Windelband, Humova ontologická skepse implikuje, že člověku je sice dána zkušenost, avšak nikoliv možnost dospět $\mathrm{k}$ vědě o zkušenosti. Hume je v souladu s tím pokládán za reprezentanta empirického probabilismu. (Srv. Wilhelm Windelband, Die Geschichte der neueren Philosophie I, Breitkof \& Härtel, Leipzig 1922, str. 345-347.) 
lepšího, než je Humovo pojetí kauzality. ${ }^{51}$ Jestliže tedy vypudil Hume za pomoci tohoto pojetí Boha jakožto první př́ičnu oknem, vrací se mu zase dveřmi v podobě stálé a nezrušitelné možnosti zázraků.

Co se týče vztahu náboženství a mravnosti, je Humovým východiskem tvrzení, že oproti univerzálním, všem lidem ve všech dobách vlastním pudům nebo přirozeným sklonům, jakými jsou sebeláska, pohlavní náklonnost, láska ke zplozencům, vděčnost, mstivost a mravní cit sympatie-empatie, jsou náboženské zásady něčím sekundárním, nebot’ se „snadno dají porušit různými náhodami, vnějšími příčinami nebo sběhem okolností"; 52 matkou náboženství je podle Huma nevědomost a (můžeme-li dodat zcela v Humových intencích) jeho otcem je strach. $\mathrm{Na}$ druhé straně mravnost podle skotského skeptika závisí pouze na zmíněných „primárních“ citech: když nějaký čin či kvalita mysli v nás určitým zpơsobem vzbuzuje libost, ř́káme, že jsou ctnostné; a když její zanedbávání či nevykonávání v nás podobným způsobem budí nelibost, říkáme, že máme povinnost ji vykonávat. ${ }^{53}$ Zmiňme ještě, že podle Huma jsme - skrze přirozené fungování mravních citů - hrdi na tehdy, když máme nějakou vlastnost, která nás činí láskyhodnými. Z toho jednoznačně plyne, že člověk může jednat mravně, aniž $\mathrm{k}$ tomu potřebuje transcendentně-náboženskou sankci - jeho mravní spontaneita se projevuje tím, že (pokud je vpravdě ctnostný) „je puzen ke své povinnosti bez všelikého násilí a bez námahy“. I u ctností, které "jjou obtížnější a více založeny na uvažování“, jak jsou např. „duch pospolitý, poctivost či střídmost“, realizuje se podle Huma závaznost bez jakékoli naděje, že by se tím získala náboženská zásluha, nebot' ctnostné jednání se zde pokládá zcela prostě za povinnost vůči společnosti, resp. za povinnost jednajících vůči sobě samým. Hume v této souvislosti prezentuje následující paradox: Ačkoliv neexistuje člověk do té míry hloupý, že by nepokládal ctnost a počestnost za nejcennější vlastnosti, jichž se vůbec někomu může dostat, přesto lidé nechtějí, aby náboženství (anebo alespoň jeho hlavní část) tkvělo v usilování o tyto vlastnosti; místo toho, aby kladli podstatu náboženství do ctnosti a mravnosti, považují za ni návštěvu kázání.

V souladu s tímto náhledem, který ovšem (jak dnes víme) postihuje jen degenerovanou a jeho původnímu smyslu odcizenou podobu křest́anství, podle Huma platí, že náboženství odvádí lidi od jejich přirozených mravních inklinací, protože zavádí nový a "frivolní“ druh zásluh; touha získat od Boha odměnu za tyto zásluhy (které spočívají v chození do kostela, zapalování svíček, přeříkávání modliteb, prokazování schopnosti citovat z posvátných posvátné knihy a ve

51 Dr. Johnson, který odmítá Humovo vyvrácení zázraků, je např. nucen připustit, že Bůh, který zázraky činí nebo dopouští, musí za tímto účelem suspendovat "pevné přírodní zákony“, jimiž řídí přírodu. (Srv. James Boswell, Život Samuela Johnsona, Václav Petr, Praha 1930, str. 154.)

$52 P R$, str. 4.

${ }^{53}$ Srv. The Philosophical Works of David Hume, Vol. II, str. 292. 
vzbuzování zdání zbožnosti) je pro pověrčivého člověka důležitější než chovat se mravně, nebot” „v mravním jednání nenalézá pověrčivý člověk ničeho, co by byl vykonal vlastně pro své božstvo, anebo co by mu mohlo obzvláště získat milosti a ochrany boží“. Pověrčivý člověk nevěnuje mravnímu jednání zdaleka tolik sil, kolik jich věnuje pověrečným rituálům; nechápe, že nejpřirozenějším zpo̊sobem, jak sloužit božstvu, je péče o blaho jím stvořených bytostí, a stále hledá nějaký bezprostřednějším zposob služby nejvyšší Bytosti, ,jen aby utišil onu hrůzu, jež jej pronásleduje“ ${ }^{54}$

Hume tedy dospívá k závěru (který je nám dobře známý v masarykovské transpozici), že jedině správným zpo̊sobem, jak milovat Boha, je milovat naše bližní, 55 přesněji bychom ovšem měli místo „milovat Boha“ říci „naplňovat citový vztah k Bohu“, protože Humova koncepce přirozené mravnosti implikuje, že láska k Bohu je nepřirozená - Hume sám klade důraz hlavně na to, že citovým pojítkem člověka k Bohu je strach.

Myšlenkou redukce náboženství na lásku k bližnímu čili na „humanitu“ se Hume dostává na pozici, která je v zásadním souladu s dialektickým vývojem Hegelovy Fenomenologie ducha: Hegel totiž spatřuje pravý smysl (prvotního) křest’anství („nešt́astného vědomí“) nikoliv v prodlévání v neřešitelných rozporech, nýbrž v ustavení všeobecného společenství lidí spjatých mravními a emocionálními vztahy lásky k bližnímu, tj. společenství, v němž jednotlivec poznává radost, nebot' v něm nalézá sebe sama a uvědomuje si své usmíření s všeobecností. ${ }^{56}$

Jestliže tedy Hume prokázal (jak se alespoň domníval), že náboženství škodí mravnosti, ${ }^{57}$ pak z toho plyne netoliko tvrzení, že i ateista může žít mravným

\footnotetext{
${ }^{54}$ Hume dokládá tuto svou analýzu pověrčivosti četnými příklady z historie, z nichž pro ilustraci uved'me alespoň jeden: „V Aigině strana jedna, spiknuvši se, barbarsky a úkladně povraždila sedm set svých spoluobčanů, a šla v zuřivosti své tak daleko, že, když ubohý jeden uprchlík utekl se ke chrámu, vrazi utáli mu ruce, jimiž se držel brány a odvlekše jej s posvátné půdy, ihned jej zavraždili. Touto bezbožností, praví Herodot (nikoli jinými četnými krutými vraždami), urazili bohy a dopustili se neodpustitelného provinění." (PR, str. 72.)

${ }^{55}$ Myšlenku oddělení mravnosti od náboženství vyjádřil v poněkud mírnější (a tudíž adekvátnější formě) Pascal svým výrokem, v souladu s nímž někteří věřící milují Boha proto tak silně, aby již nemuseli milovat nikoho jiného. Zajímavým dokladem způsobu, jímž se Humova myšlenka vyjadřující správnost převedení citového a energetického potenciálu náboženských činností do láskyplných vztahů mezi lidmi zasáhla (na základě toho, že ji recipoval Masaryk) do našeho československého nábožensko-politického dění, je reakce slovenských katolíků na přednášku Alice Masarykové, kterou proslovila v březnu 1919 v Bratislavě; zní následovně: „,V tejto prednáške ráčili ste hovorit', že náboženstvo je úcta k človeku, alebo prichylnost' k rodine, alebo láska k diet'at'u. My pak vieme, že náboženstvo je dačo iného: je to úcta a láska $\mathrm{k}$ Bohu. Kto človeka, diet́a, rodinu nábožensky ctí a miluje, kto ho zbožňuje, je pohan, modloslužobník. Náboženstvo smeruje $\mathrm{k}$ jedinému a pravdivému Bohu. Láska k diet’at́u je láska, a nie náboženstvo. Neplet'te si, prosím, koše s baňami... Ctíme Vás, a ešte viac by sme ctili, keby ste nám len o takových veciach drželi prednášky, ktorým rozumiete." (Cit. in Ferdinand Peroutka, Budování státu II, Lidové noviny, Praha 1991, str. 794.)

${ }^{56}$ Srv. G. W. F. Hegel, Fenomenologie ducha, str. 169, 177, 504.

${ }^{57}$ Hume věrný své opatrné prozíravosti nicméně říká, že mravnosti škodí „lidové“ náboženství.
} 
životem, nýbrž také silnější tvrzení, a sice že mravným životem může žít jedině ateista. Pravdivost prvního tvrzení potvrdil Hume svým životem; k problematice druhého, silnějšího tvrzení, se ještě vrátíme v závěru.

Výklad Humova poměru k náboženství by byl značně neúplný, kdybychom alespoň v krátkosti nezmínili interpretační tradici, v níž je skotský filosof prezentován jako konzervativec (ve smyslu odpovídajícím významu slova tory). Typické rysy této interpretace (jež se opírá ponejvíce o Humovy slavné Dějiny Anglie) lze najít u Donalda W. Livingstona, který vychází z Humova rozlišení mezi „pravou“ (true) a „falešnou“ (false) filosofií, prezentovaného již v raném Traktátu. ${ }^{58}$

Podle Huma sestává „pravá“ filosofie z metodicky uspořádaných a korigovaných reflexí „běžného života" (common life), 59 zatímco "falešná“ filosofie se vyznačuje směřováním k nejzazšímu (ultimacy), autonomií čili sebeurčováním (což znamená, že se filosof nemůže - pokud má zůstat filosofem - podřizovat předreflexivní autoritě zvyků, tradic či dogmatům kněží a básníků), a konečně tím, že si ze stanoviska filosofického rozumu činí nárok na ovládání onoho „běžného“ (předreflexivního) života. Hume ještě dodává, že autonomní filosofický rozum, odtržený od předreflexivní sféry, nemůže sám ze sebe dospět k žádnému soudu, z čehož plyne, že filosofové tajně vpašovávají do svých výtvorů své oblíbené předreflexivní či předfilosofické předsudky a prezentují je posléze v podobě univerzálních principů zcela nezávislých na autoritě zvyklostí. Klamou přitom sebe sama i ostatní; vzhledem k tomu, že proklamovaným cíl filosofie má podobu imperativu „poznej sebe sama!“, je takto si počínající filosofický rozum falešný v modu sebeklamu.

„Falešnou“ filosofii v právě nastíněném humovském pojetí pak Livingston ztotožňuje s ideologií; tento jeho počin je značně problematický, nebot' operuje pouze s Marxovým (či Marxovu pojetí blízkým) pojetím ideologie jakožto falešného vědomí, přičemž zcela zanedbává jiná pojetí ideologie, zejména pak pojetí Hayekovo, v němž je ideologicko-dogmatická obrana svobody nezbytnou součástí fungování svobodné společnosti. Jiným povážlivým důsledkem Livingstonova přístupu je, že při ztotožnění humovské "falešné" filosofie s ideologií by se ideologem stal například Kant či Husserl (navzdory tomu, že jeho koncepce přirozeného světa má některé styčné body s Humovým chápáním „běžného života“), což je opravdu stěží přijatelné.

Livingston dále uvádí vymezení R. Kirka, v souladu s nímž je podstatným rysem konzervativní tradice kritika ideologie v politice (paradigmaticky v té podobě, v jaké

58 Srv. Donald W. Livingston, David Hume and the Conservative Tradition, http://www.firstprinciplesjournal.com/articles.aspx?article=1312

${ }^{59} \mathrm{~K}$ otázce správného českého překladu Humova termínu common life viz Zdeněk Novotný, David Hume a jeho common life. Historie jedné dezinterpretace, in: Filosofický časopis, FÚ AV ČR Praha, 2010/3, str. 413-425. 
ji uplatnil Burke ve svých Úvahách o revoluci ve Francii). Toto vymezení uvádí Livingston $\mathrm{v}$ souvislost $\mathrm{s}$ tím rysem Humova pojetí křest'anství, v němž skotský myslitel zdůrazňuje, že křest́anství, původně zakotvené v posvátné tradici, do sebe později absorbovalo „falešnou“ řeckou filosofii, což vedlo k tomu, že z křest́anů stali rozumující teologové odtržení od „běžného života“ a dokonce se stavící nepřátelsky vůči němu. Připomíná i Humovu kritiku politických stran jeho doby, v níž Hume zdůrazňuje, že každá z nich nalézá ve své politické praxi podporu v "anektovaných“ filosofických či spekulativních systémech. Livingstonův závěr je pak jednoznačný: Jelikož Hume kritizuje implementaci „falešné“ filosofie (tj. ideologie) v náboženství v politice, je netoliko konzervativcem, nýbrž přímo klasikem konzervativismu, naplnivším zásady konzervativního přístupu ještě před Edmundem Burkem. ${ }^{60}$

S tímto závěrem lze povšechně souhlasit, nebot' Hume je filosofický Próteus, jemuž nechybí ani konzervativní tvář. ${ }^{61} \mathrm{~V}$ oblasti, kterou sledujeme, nachází Livingstonova interpretace podporu i v Humově rozlišení mezi puritanismem a katolicismem: zatímco puritanismus, jsa především spirituální, se podobá víc metafyzickému systému než náboženství, je katolicismus „rozumnějši“”, protože je přizpůsoben smyslovým prožitkům nařizuje obřady, které se přibližují „obyčejnému běhu života“" (common train of life). Mnohem problematičtější je Livingstonův odkaz k Humovu tvrzení, že víra v teleologicky působícího (jediného) Tvůrce univerza není pouze v souladu s našimi přirozenými (předreflexivními) prožitky víry, nýbrž je ve skutečnosti jejich předpokladem. Je totiž zcela zřejmé, že toto tvrzení nelze aplikovat na tradiční polyteistická náboženství (např. na náboženství řecké, v jehož mytologii kosmos spontánně povstává $\mathrm{z}$ chaosu). ${ }^{62}$ Navíc, jak již bylo řečeno, faktická

${ }^{60}$ Humova konzervativní kritika ideologizovaného puritánství a jeho politiky (podložená ovšem jeho osobní zaujatostí proti puritánskému horlitelství) byla v jeho Dějinách Anglie spojena s glorifikací jejich odpůrců; to se projevilo např. tím, že puritány charakterizuje Hume jako tmářské, nerozumné a pokrytecké fanatiky (takovým je i Cromwell), zatímco král Karel I. je vykreslen jako vzor všech ctností. Pokud přiznává zásluhy puritánům (což je zcela výjimečné v celém tomto rozsáhlém historickém díle), činí tak v podobě paradoxního tvrzení, že Angličané vděčí za veškerou svobodu své ústavy sektě, jejíž principy jsou frivolní a jejíž zvyklosti směšné. (Srv. James Orr, ibid., str. 230.) Proto nepřekvapuje, že Humovy Dějiny četl se zálibou francouzský král Ludvík XVI. (a že si je po svém odsouzení k smrti vyžádal, aby prostudoval chování Karla I. v analogické situaci), že odpưrci Francouzské revoluce z nich vyčetli, že to, proti čemu bojovali, je duchovní patologie (a to ještě předtím, než revoluci v tomto smyslu charakterizoval ve svých Úvahách Burke) a že toto Humovo dílo ovlivnilo takové francouzské konzervativce, jakými byli Joseph de Maistre a Louis de Bonald (o němž pro zajímavost lze zmínit, že byl Hayekem označen jako reakcionář). Také Livingstonem (ibid.) uváděná paralela mezi Humovým pojetím „falešné“ filosofie a Camusovým tvrzením, že filosofie (ve XX. století) může být použita i pro proměnu vrahů v soudce, je zcela patřičná.

61 Hume je ovšem pouze "negativním" konzervativcem, protože v Kirkově vymezení konzervativismu, které aplikuje Livingston, chybí pozitivní rysy konzervativní orientace, jak je např. důraz na respekt vůči autoritám či ono nerozlučné propojení oltáře a trůnu, které tak výmluvně popsal Burke ve výše citované pasáži. S Humovou "negativne“-konzervativní orientací je navíc $\mathrm{v}$ rozporu jeho myšlenka přeměny politiky ve vědu, kterou jsme uvedli v první části tohoto pojednání. 62 Pokud bychom (v kantovském duchu) tvrdili, že víra v teleologicky činícího Tvưrce světa je apriorní ideou naší mysli, mohli bychom problémy spojené s prevalencí polyteismu v tradičních náboženstvích 
existence víry v Tvưrce vesmíru v myslích lidí ještě nezaručuje jeho skutečnou jsoucnost. K tomu, aby se zmíněné Humovo tvrzení dalo chápat jako přitakání religiozitě, by musel Hume sám postupovat striktně v souladu se svým vymezením „pravé“ filosofie, tj. metodicky pořádat instance přirozené víry; je však všeobecně známo, že - jakožto skeptik a autor spisů o náboženství - tak nepostupoval. ${ }^{63}$

V souvislosti stouto problematikouotázkami se musí Livingston vyrovnat i s otázkou Humova skepticismu: traktuje ho jako „moment v dialektice pravé a falešné filosofie, který nutně plyne z autonomie filosofie, jež popírá autoritu předreflexivního“. Moment skepticismu je překonán, když se již v rámci "pravé“ filosofie dospěje k poznání, že o zvyku je třeba předpokládat, že je pravdivý, pokud se neukáže, že tomu tak není. K tomu můžeme říci, že když srovnáme Humův Traktát zejména s jeho Dějinami Anglie, tak k takovémuto „překonání“ skepticismu u Huma skutečně došlo; uskutečnilo se však jen v podobě implicitní - explicitně se konzervativní Hume se svým dřívějším skepticismem nevyrovnal. ${ }^{64}$

\section{Hume vs darwinistický evolucionismus}

Východisko Humovy anticipace evolučního pojetí, v souladu s nímž se účelně uspořádané živé organismy vyvinuly v procesu samoorganizace hmoty neboli bez teleologického působení inteligentního Tvůrce, lze spatřovat v Humově výroku (vloženém do úst Filónovi), který přímo šokuje každého, kdo je povšechně

řešit poukazem na to, že onu apriorní ideu Boha-tvưrce je nutno odhalit trpělivou prací transcendentální reflexe; z pozice Humova rozlišení mezi „pravou“ a „falešnou“ filosofii je takovéto řešení vyloučené.

63 Pokud bychom připustili, že Hume v konzervativním duchu uznává nezbytnost propojení náboženství a (konzervativní) politiky, muselo by - v souladu s jeho kritikou ideologizovaného či teologizovaného náboženství - do tohoto propojení vstoupit jakési ryze předreflexivní tradiční náboženství, které ovšem v Evropě v té době neexistovalo (wesleyovský program citové vroucnosti, který se nejvíc přibližuje Humově představě dezideologizovaného náboženství, není tradičním náboženstvím, nýbrž plodem reflexivního hledání východiska z krize). Koncept teleologicky působícího Tvůrce je též, jak jsme ukázali, plodem filosofické reflexe; i kdybychom připustili, že v tomto případě jde o "pravou“ filosofii, která „koriguje“ instance předreflexivní víry, nemůže př́itomnost onoho konceptu v myslích lidí suplovat společensko-politické fungování náboženství; podle výše uvedeného autoritativního vyjádření pruského krále je deistická redukce Boha na abstraktní koncept naopak smrtelným nebezpečím pro náboženství jakožto reálné společenské instituce.

64 „Překonání“ skepticismu se v Humových Dějinách projevuje v tvrzeních typu „účinky budou vždy odpovídat př́činám", „účinky lze dedukovat z př́čin s dokonalou jistotou“; také principy, na nichž zde Hume staví své dedukce, jsou "věčné a neměnné pravdy“; i imprese a ideje mizí - místo toho stojíme na půdě obecného lidství. (Srv. James Orr, ibid. str. 218-219.) Orr dodává, že čtenář se na touto Humovou proměnou někdy stěží ubrání pousmání. Též v eseji „Skeptik“ nalézáme krásný exemplár̆ teorie odrazu: „Když zkoumám ptolemaiovský a kopernikánský systém, usiluji pouze o to, abych poznal skutečné postavení planet, jinými slovy snažím se jim dát ve svém chápání stejné vztahy, jaké mezi sebou mají na nebesích. Zdá se tedy, že pro tuto činnost mysli existuje vždycky v přirozenosti věcí nějaké skutečné, byt' často neznámé kritérium." (David Hume, Skeptik, in: Filosofický časopis, FÚ AV ČR Praha, 2008/2, str. 172.) 
obeznámen s Humovým empirismem, nebot' obsahuje myšlenku, že a priori víme, že hmota může obsahovat zdroj nebo původ řádu prvotně sama v sobě. ${ }^{65}$ Platnost této myšlenky zdůvodňuje Hume poukazem na to, že není nijak obtížnější pochopit (conceive), že jednotlivé prvky hmoty (Hume má zde spíše na mysli imprese, jimiž jsou prvky snad existující transcendentní hmoty reprezentovány v imanenci naší mysli) se mohou na základě jakési „vnitřní“ neznámé př́čciny octnout v tom nejdokonalejším uspořádání (fall into the most exquisite arrangement), než pochopit, že jejich ideje se ve „veliké univerzální mysli“ neboli v mysli Boží ocitají v onom uspořádání působením podobné neznámé př́ičiny.

K tomu, abychom plně porozuměli, proč zde Hume mluví o apriorním poznání, musíme v krátkosti zmínit jeho kritiku svobody vůle. Jejím hlavním motivem bylo patrně Humovo domyšlení etických důsledků jeho koncepce oblasti vnitřní zkušenosti jakožto svazku percepcí, které jsou v neustálém toku a pohybu; pokud by totiž mezi oněmi percepcemi (tj. prvky vnitřní zkušenosti) neexistovala žádná kauzální determinace, pak by platilo, že ten z prvků, který vedl třeba k tomu, že jsme spáchali zločin, nijak nesouvisel sostatními prvky naší pseudo-osobnosti; při neustálém toku a proměně těchto prvků by se rovněž mohlo stát, že by ona pseudoosobnost (tvořená vždy jen svazkem prvků) byla v okamžiku, kdy by byla za svůj čin potrestána, zcela odlišná od pseudo-osobnosti, která spáchala zločin. To by ovšem znamenalo, že nejsme a nijak ani nemůžeme být odpovědni za své činy, nebot' „odpovědným“ by byl pouze atomární, s jinými prvky nijak nesouvisející „zločinný“ prvek, který mezitím ve stálém toku vnitřního dění zanikl;66 udržet jednotu svobodné vưle a odpovědnosti je totiž možné pouze na bázi duše jakožto nezjevného sebeidentického základu našeho vnitřního života - a duše je právě tím, co Hume zamítá.

Se zřetelem k těmto nebezpečným implikacím činí tedy Hume pokus o restituci jednoty naší osobnosti tím, že mezi její plynoucí prvky vkládá kauzální determinaci. Je si však dobře vědom toho. že klasické ontologické pojetí kauzality nelze aplikovat na naše vnitřní prožívání (uplatnění kauzality na náš psychický život zamítl později i Kant). Přichází proto s nám již dobře známým pojetím kauzality jakožto víry založené na obvyklosti, které aplikuje nejen na oblast psychična (tj. vnitřního vnímání), nýbrž i na přírodu (tj. na oblast vnějšího vnímání čili na imprese). Ve výsledku pak platí, že ve „hmotném“ světě panuje stejná (přesněji řečeno stejně slabá) míra kauzální nutnosti, jako ve vnitřním světě naší psychiky. Jinými slovy, myšlenku univerzálního kauzálního determinismu (zahrnujícího vnější i vnitřní

${ }^{65}$ Srv. $P R$, str. 106.

${ }^{66}$ Srv. ZR, str. 139-140. 
zkušenost) ${ }^{67}$ mohl Hume uplatnit jen za podmínky, že regularitu př́rodního dění připodobnil mnohem slabší regularitě dění psychického; musel přitom (vzhledem $\mathrm{k}$ přírodě) zamítnout představu silového propojení mezi prŕčinou a účinkem, protože takovéto propojení v naší psychice neexistuje. ${ }^{68}$

Zde se nám také objasňuje, proč Hume mluví o apriorním poznání samoorganizace hmoty, resp. „hmoty“ našich impresí. Neznamená to, že bychom se mohli ponořit do Boží mysli a nahlédnout tam způsob, jak se v této mysli ustavují plány organismů; stačí pouze nahlédnout do naší vlastní mysli, v núž se také spontánně (vlivem neznámých "přičin“) ustavují plány našich produktů a účely našich činů. ${ }^{69}$ Jelikož stejný typ kauzality musí nutně působit i ve hmotě, je $a$ priori zřejmé, že hmota - podobně jako naše vlastní mysl - má schopnost spontánní samoorganizace. Přes sebevětší výhrady, které můžeme vznášet proti Humově koncepci kauzality, je jeho myšlenka apriorního poznání samoorganizace hmoty vpravdě geniálním výkonem.

K myšlence samoorganizace hmoty dospěl Hume i na základě svého ateismu. Pokud totiž platí, že Bůh neexistuje, znamená to, že druhové podstaty živých bytostí se nemohou vyznačovat absolutní sebeidentitou a časovou neměnností své vzájemné rozlišenosti, nebot' takovými by mohly být jenom tehdy, kdyby byly tvořeny a udržovány Boží myslí. Humova kritika ontologického statusu substance, v souladu s níž druhové podstaty jakožto nehmotná ideální jsoucna neexistují, vedla zároveň k závěru, že pokud si živé druhy (a také jednotlivé účelně uspořádané organismy) zachovávají totožnost $\mathrm{v}$ čase, jde o relativní totožnost, která je ustavována a udržována pohybem hmoty, tj. bez jakéhokoliv Božího záměru a plánu, nebot' „hmota může nabýt pohybu bez jakéhokoli úmyslného činitele nebo prvého

\footnotetext{
${ }^{67}$ Náhoda podle Hume vůbec neexistuje; každá věc je ovládána pevnými, neporušitelnými zákony (governed by steady, inviolable laws). (Srv. PR, str. 141.)

${ }^{68} \mathrm{~V}$ souvislosti s naší tezí, že vše důležité v Humovi má relevanci pro jeho kritiku náboženství, je třeba zmínit, že v první polovině 17. století arcibiskup Laud a královský dvůr přijali učení holandského biskupa Arminia, které hlásalo svobodnou vůli, zatímco členové i přívrženci parlamentu věřili po kalvínsko-augustinovském způsobu v predestinaci. Teze svobodné vưle se tudíž spojovala se zájmy despotické vlády, deterministická teze predestinace s obranou výsad parlamentu. (Srv. André Maurois, ibid., str. 249.) Přes svou známou averzi vůči nábožensky zaníceným puritánům se Hume mohl k popírání svobody vůle dopracovat i z těchto nábožensko-politických důvodů, a to tím spíše, že i v jeho době byly spory s arminiánstvím živé (např. v r. 1754 vystoupil proti němu význačný kalvinista Jonathan Edwards); za "Velké Rebelie“ byli ostatně za puritány pokládáni i ti, kdož chtěli, aby jim vládly jen zákony. Z Humova hlediska musela kromě toho být doktrína svobodné vůle daleko integrálněji spojena s křest'anstvím, než je tomu v př́ípadě kalvínského predestinacionismu. Humovo popření svobodné vůle (kterou považuje za "falešnou impresi“) je exemplárním prrípadem postoje klasických liberálů, kteří si daleko výš než metafyzické, a tudíž neprokazatelné svobody cení jednotlivé empiricky testovatelné "svobody od“. Je ostatně příznačné, že Sartre jakožto nejhlasitěǰś hlasatel oné metafyzické svobody inklinoval postupně k marxismu, maoismu i terorismu.

${ }^{69}$ Srv. PR, str. 106.
} 
hybatele“. ${ }^{70}$ Humova anticipace evolucionismu se odvijí také od jeho jasného uchopení fenoménu boje o přežití. ${ }^{71}$

Konkrétní pochopení mechanismu samoorganizace hmoty se u Huma odvíjí od předpokladu konečného množství hmotných části, které jsou v rámci „věčného trvání“ hmoty s to zaujmout pouze konečný celkových počet konfigurací. [Hume vlastně mluví o konečném množství přemístění (transpositions), což ukazuje, že nebyl s to překonat dobový mechanistický materialismus.] To mimochodem implikuje, že v nekonečném trvání se každá možná celková konfigurace částic musí realizovat v nekonečném množství opakování a že tudíž „tento svět se všemi svými ději“ existoval již dřive a po svém zničení bude opět utvořen (produced) a zase zničen a tak stále dál bez jakéhokoliv omezení. Jak patrno, Hume zde skoro doslova anticipuje Nietzschovo zdůvodnění věčného návratu stejného; na rozdíl od tohoto německého iracionalisty (a také evolucionisty), jenž byl tímto motivem přímo fascinován, se jím Hume již dále nezabývá.

Klade si totiž otázku, zda existuje taková celková konfigurace částic, v jejímž rámci by si hmota mohla uchovat svůj neustálý pohyb a zároveň tímto pohybem udržovat ve stálosti či relativní totožnosti jednotlivé tvary, které jsou součástmi oné celkové konfigurace; zde je zřejmé, že pod termínem tvar (form) míní Hume jak jednotlivé organismy, tak jejich druhy. Odpověd' na tuto otázku je kladná, protože právě tak se skutečně mají věci v našem světě; to znamená, že toto (existující) uspořádání se vytvořilo stálým pohybem hmoty poté, co se na jeho základě realizoval počet jiných celkových konfigurací menší než nekonečno. Nynější celková konfigurace se pak vyznačuje tím, že řád v ní obsažený udržuje sám sebe svou vlastní přirozeností „po mnohé věky, ne-li na věčnost“. Jak vidět, oproti předchozí koncepci „věčného návratu stejného“" se zde objevuje motiv nevratnosti evolučního procesu - pokud je totiž dosaženo řádu, který je s to reprodukovat sebe sama, může

\footnotetext{
70 Působení nehmotného hybatele resp. tvưrce účelného uspořádání organismu vyvrací Hume mj. zkušenostně založeným tvrzením, že ideje jsou kopiemi předmětů skutečných (tj. impresí) - kvůli zdůraznění svého antiplatonismu dodává, že v učeném vyjádření jsou ideje nikoliv archetypální, nýbrž ektypální; ti, kdož věří, že idea může uvést v pohyb hmotu, převracejí tento pořádek a ignorují, že myšlení může mít vliv na hmotu jen tehdy, je-li s ní sdruženo. $\mathrm{V}$ tom př́ípadě je však nutno připustit, že i hmota má vliv na myšlení, nebot ",stejnost účinu a protiúčinu jest všeobecným zákonem přírody“. Z toho pak vyvozuje, že to, že hmotě je pohyb inherentní (na základě tíže, pružnosti, elektřiny), je právě tak apriorně myslitelné, jako je apriorně myslitelné to, že pohyb je hmotě udělován duchem a rozumem; dodává též, že snad není ani jediná částice hmoty, která by byla v naprostém klidu. (Srv. PR, str. 154-155.)

71 „A proč by se člověk (...) měl domáhat vyjmutí z osudu všech ostatních živočichu? Celá země jest (...) prokleta a poskvrněna. Neustálý boj zuři mezi všemi živoucími tvory. Nutnost, hlad, nouze pohánějí silné a zmužilé; strach, úzkost a hrůza zmítají slabými a chabými. (...) Kdo silnější, pronásleduje slabšího a udržuje ho ve stálé hrůze a bázni. Často zase slabší stihají silné, týrajíce a trápíce je bez ustání. (...) A tak jest každý živočich na všechny strany vpředu i vzadu, nahoře i dole obklopen nepřáteli, usilujícími neustále o jeho strast a zhoubu.“ (PR, str. 164.)
} 
tento řád odolávat protichůdně působícím silám (neboli procesům zvyšujícím entropii) přinejmenším nesrovnatelně déle než kterákoliv celková konfigurace, které schází schopnost sebereprodukce, a tudíž existuje jen v přechodu v jinou celkovou konfiguraci.

Pokud si v rámci zmíněné konfigurace uchovávají jednotlivé organismy i jejich druhy stálost zprostředkovanou neustálým pohybem, pak podle Huma platí, že reprodukující se řád obsažený $v$ těchto organismech i v jejich vzájemných vztazích se musí zdát výtvorem dovednosti a záměru (artifice and contrivance) či myšlení a umění, které je podobné lidskému; je tomu tak proto, že všechny části každého organismu musejí být ve vzájemném vztahu mezi sebou i k organismu jako celku, který zase musí být ve vztahu k ostatním částem vesmíru, a sice k živlu, v němž existuje, k látkám, které jsou materiálem, jímž nahrazuje to, co ztrácí a co v něm zaniká, a ke každému jinému živému organismu, at' již přátelskému nebo nepřátelskému. (Podle Huma i sám vesmír jako celek je natolik uspořádaný, že má podobný charakter jako organismus.) $)^{72}$

Představa, že by řád vlastní jednotlivému organismu i vesmíru jako celku (dnes bychom ovšem skromněji řekli „ekosystému jako celku“) musí být nutně dílem inteligentního Tvưrce, je však jen pouhým zdáním: pokud totiž platí, že žádný organismus nemůže trvat, nemá-li ty síly a orgány, které jsou nezbytné pro jeho trvání či přežití (subsistence), pak v případě, že v rámci nějaké konfigurace tomu tak není, musí být ( $v$ rámci další konfigurace) vyzkoušeno (tried) nějaké nové uspořádání či nová ekonomičnost (economy), a to opět a opět, bez ustání, až se nakonec připadne (fall upon) na nějaké nové uspořádání, které je s to živit (support) a udržovat samo sebe. ${ }^{73}$

V této pasáží dospívá Hume k vrcholnému bodu své anticipace darwinistického evolucionismu; právě ji cituje Hayek na podporu svého tvrzení, že evoluční pojetí se prvotně zrodilo při zkoumání evoluce společenských institucí a že bylo teprve mnohem později aplikováno na organickou přírodu. ${ }^{74}$

\footnotetext{
72 Srv. PR, str. 143, 151.

${ }^{73}$ Srv. $P R$, str. 154.

74 Viz Friedrich A. Hayek, Osudná domýšlivost, Sociologické nakladatelství, Praha 1995, str. 156. Hayek ovšem (perfidně) nedodává, že Humův termín form (který jsme v našem výkladu nahradili termínem „organismus“) neoznačuje obecně komplexní útvar, který může být jak organicko-přírodní, tak společenské povahy, nýbrž právě př́rodní organismus. Diskuse o tom, zdali Hume ve své teorii geneze společenských institucí nalezl uplatnění pro evoluční proceduru pokusu a omylu, jejímž kriteriem je schopnost přežít a vítězit v konkurenčním boji, by daleko přesáhla stanovený rámec tohoto př́ispěvku. Proto se zatím spokojíme s tím, že doporučíme pozornosti čtenáře Humovo použití termínu economy při popisu organického rádu.
} 
Nyní ještě uvedeme zajímavé paralely mezi Humovými a Darwinovými texty, které nalezl a zveřejnil profesor biologie Michael Pallen;75 nejsou sice důkazem, nýbrž pouze indicií, že Darwin při koncipování svého základního $O$ vzniku druhů př́rodním výběrem byl velmi pravděpodobně ovlivněn četbou Humových Dialogů o prírozeném náboženstuí. Necháme je bez komentáře, protože je pokládáme za dostatečně výmluvné.

\section{Paralela 1}

Darwin: „Nedíváme-li se už na organismy jako divoch na lod', tedy jako na něco zcela nepochopitelného, chápeme-li každý výtvor přírody jako něco, co má za sebou své dějiny, díváme-li se na každou složitou stavbu a instinkt jako na souhrn mnoha mechanismů, z nichž každý byl svému majiteli užitečný, zhruba stejně jako je každý velký mechanický vynález souhrnem práce, zkušenosti, rozumu a dokonce i chyb četných pracovníků, a díváme-li se takto na každý organismus, jak daleko zajímavějším (to říkám z vlastní zkušenosti) se stane studium přírodovědy!“76

Hume: „Ale bud' si tento svět výtvorem sebe dokonalejším, vždy musí zůstat nejistým, lze li všechny výbornosti toho díla právem přisoudit zhotoviteli. Hledíme-li na lod', jak neobyčejným musí se nám jevit důmysl tesaře, jenž zhotovil stroj tak složitý, užitečný a krásný! A jak musíme být překvapeni, když shledáme $\mathrm{v}$ něm tupého řemeslníka, jenž napodobil jiné a otrocky se přidržoval dovednosti, která se po dlouhou řadu věků postupně zdokonalovala po mnohonásobných pokusech, pochybeních, opravách, přemítáních a sporech! Co tu po celou věčnost mohlo být zbříděno a zhudlařeno světů, než se tato soustava povedla; co práce ztraceno, co planých pokusů naděláno; a jak zdlouhavě, avšak bez přestávky mohlo být pokračováno ve zdokonalování se $\mathrm{v}$ umění stavby světa po nekonečné věky! Kdož může $\mathrm{v}$ takových věcech stanovit, kde se nalézá pravda, ba kdo jen hádat, kde pravděpodobnost uprostřed velikého počtu domněnek, jež lze pronést a většího ještě počtu těch, jež lze si pomyslit?77

\section{Paralela 2}

Darwin: "Ale ještě pádnější je důkaz, který nám dávají naše domácí zvířata četných druhů, zdivočelá v mnoha oblastech světa. Kdyby nebyla tvrzení o rychlosti množení jinak pomalu se rozmnožujícího hovězího dobytka a koní v Jižní Americe a později i v Austrálii dostatečně ověřená, nedalo by se jim věřit. Tak je tomu i s

\footnotetext{
${ }^{75} \mathrm{Viz} \quad \underline{\mathrm{http}}$ // roughguidetoevolution.blogspot.com/2009/06/david-humes-influence-on-charlesdarwin.html.

${ }^{76}$ Charles Darwin, O vzniku druhů prírodním výběrem, Academia, Praha 2007, str. 541.

77 David Hume, $P R$, str. 131-132.
} 
rostlinami. Lze uvést případy zavlečených rostlin, které se zabydlely na celé ploše několika ostrovů $\mathrm{v}$ období kratším než deset let. Některé rostliny, jako artyčok kardový nebo bodlák druhu Cirsium a/tissimum, které nyní rostou v ohromných množstvích na širých pláních La Platy a pokrývají celé čtvereční mne plochy, odkud vytlačují všechny ostatní rostliny, byly zavlečeny z Evropy. V Indii jsou zase rozšířeny rostliny od mysu Komorin až po Himálaje, které byly dovezeny z Ameriky po jejím objevení. “78

Hume: „Lucullus první přinesl třešňové stromy do Evropy, ač se stromu tomuto tak dobře daří ve mnohých evropských. podnebích, že roste $\mathrm{v}$ lesích beze všeho pěstění. Je-liž možno,. aby po celou věčnost žádný Evropan nebyl se dostal do Asie a nepomyslil na přesazení tak lahodného ovoce do vlastní své země? Anebo, když. už ten strom byl přesazen a rozmnožen, jak mohl zase vyhynout? Říše mohou povstávat a upadat; svoboda a otroctví mohou se střídat; nevědomost. a vědomost mohou jedna druhé ustupovat; avšak třešeň stále zůstane v lesích Řecka, Španělska a Itálie, a převraty lidské společnosti nikdy se jí nedotknou. Není tomu ani dva tisíce let, co vinná réva byla.přesazena do Francie, ač není podnebí ve světě, jež by jí lépe svědčilo. Není tomu ani tři sta let, co koně, krávy, ovce, vepři, psi, obilí vešli v Americe ve známost. Je-liž možno, že by v průběhu celé věčnosti nebyl povstal nějaký Kolumbus, jenž by uvedl Evropu ve spojení s onou pevninou?79

\section{Paralela 3}

Darwin: „Tento princip, podle kterého je každá nepatrná odchylka, je-li užitečná, zachována, jsem nazval přírodní výběr, abych tak naznačil jeho podobnost k výběru prováděnému člověkem. výraz přežití silnějšího, často užívaný panem Herbertem Spencerem, je však přesnější a někdy je i stejně vhodný. Viděli jsme, že člověk může výběrem dosáhnout velkých výsledků a může přizpůsobovat organismy ke svému vlastnímu užitku hromaděním nepatrných, ale užitečných odchylek, které mu poskytuje ruka přírody. Př́rodní výběr, jak později uvidíme, je však síla neustále připravená tvořit a je tak nepoměrně mocnější než chabé úsilí člověka, jako jsou díla př́irody mocnější než díla umění." 80

Hume: „Ohledněte se po světě, pozorujte celek i každou část jeho, a shledáte, že není ničím leč jediným velikým strojem, rozděleným v nekonečný počet menších strojů, jež zase dopouštějí dalších rozdělení až do takového stupně, jehož nelze již stopovat a vyložit smysly a schopnostmi lidskými. Všechny tyto rozmanité stroje, ba i nejdrobnější jejich částky, jsou vespolek seřízeny s takovou přesností, že strhuje k

\footnotetext{
78 Charles Darwin, ibid., str. 89.

${ }^{79}$ David Hume, PR, str. 139.

${ }^{80}$ Charles Darwin, ibid., str. 86.
} 
obdivu každého člověka, jenž k nim kdy obrátil zřetel. Podivuhodné přizpůsobení prostředků $\mathrm{k}$ účelům ve vší přírodě podobá se docela výtvorům lidského bystrovtipu, zámyslu, přemítání, moudrosti.a umu, ač je daleko převyšuje. Ježto tedy účinky jsou si podobny, jsme všemi pravidly analogie vedeni k závěru, že i příčiny jsou si podobny, a že Původce př́rody podobá se poněkud duchu lidskému, ač má ovšem schopnosti mnohem větší, jak toho vyžaduje velikolepost díla, jež vykonal. Tímto dovozováním a p os t e r i o r i, a jen tímto dovozováním, dokazujeme zároveň jsoucnost Božstva i podobnost jeho k duchu a umu lidskému. “81

To ovšem nejsou všechny humovsko-darwinovské paralely při formulování evolučních myšlenek; není však již potřebné, abychom se jimi zabývali. Zmiňme pouze, že za to, že přímý vliv Huma na Darwina, který s velkou pravděpodobností potvrzují, nevstoupil již dávno ve všeobecnou známost, může Humova opatrná prozíravost - málokdo by totiž čekal, že skvělé preludium k darwinismu založené na jednoznačně materialistické koncepci samoorganizace hmoty je možné nalézt ve spisu věnovaném přirozenému náboženství.

\section{Závěr}

Skutečnost, že jen ten největší Antikrist mezi všemi filosofy byl s to (v moderní době) dospět $\mathrm{k}$ myšlence evoluce realizované procedurou pokusu a omylu v rámci boje o existenci, ${ }^{82}$ je $\mathrm{v} v$ plném souladu s vývojovou logiky našeho rozumění veškerenstvu. Pokud Humovu kritiku náboženství posuzujeme pouze se zřetelem $\mathrm{k}$ tomu, do jaké míry napomohla vědeckému myšlení, pak lze oprávněně říci, že má význam přímo epochální; nicméně netoliko vědou je živ lidský duch.

Třebaže Hume prohlásil empatii za základ mravnosti, vůbec se nedovedl vcítit do nitra upřímně věřícího křest'ana; bylo to proto, že mu naprosto scházelo náboženské cítění a nemohl se tudíž ve svém přístupu k víře řídit empedoklovským nahlédnutím, že podobné se poznává podobným. ${ }^{83}$ Není vyloučené, že absence

81 David Hume, PR, str. 102-103.

82 Antický Empedoklés, který se k této myšlence také velice přiblížil, nemusel na rozdíl od Huma bojovat s vyspělým monoteismem vyzbrojeným množstvím filosofických argumentů.

83 Poznamenal-li Chesterton, že mnozí lidé "žijí ve stínu víry a ztratili světlo víry“, pak tuto poznámku lze vztáhnout na Huma beze zbytku. (Srv. Gilbert Keith Chesterton, The Everlasting Man, Garden City, NY, 1955, str. 11.) Livingston (ibid.) sice uvádí, že Humova ochota podepsat Westminsterské vyznání víry, účastnit se bohoslužeb a vést modlitby studentů prokazuje, že neodmítal posvátné náboženské tradice (což vše souviselo, jak víme, s Humovou snahou získat katedru v Edinburghu a také v Glasgowě); je však daleko pravděpodobnější, že ona Humova ochota byla výrazem jeho odhodlání přinést v zájmu ukojení své ctižádosti i jisté nepř́ijemné oběti. Kromě toho si starší z nás pamatují, že vynucená účast na rituálech reálně-socialistické společnosti leckdy přinášela zvrácený požitek pramenící z reflexe jejich naprosté absurdity a z camusovsko-sisyfovského prožitku pohrdání adresovaného jejich strůjcům. 
náboženského citu byla daní za to, že Hume byl zázračným dítětem s tak rozvinutými rozumovými schopnostmi, že byl na univerzitu přijat již ve věku dvanácti let. ${ }^{84}$ Hume nenalézá na křest'anství (které zároveň ironicky nazývá „naše nejsvatější náboženství“) doslova nic dobrého; říká o něm, že přineslo světu tu „největší bídu a devastaci“ ${ }^{85}$ Jeho sžíravé a persiflující kritické útoky na náboženství jakožto instituci a na náboženský život vůbec se (stejně jako výpady Nietzschovy v Antitkristu) staly neoddělitelnou součástí arzenálu primitivní protináboženské propagandy, jejímž příkladem může být třeba Leninův spisek $O$ významu bojovného materialismu. Pokud Hume mluví přímo proti náboženství, lze nekritičnost jeho kritiky jakž-takž tolerovat, zejména když vezmeme v úvahu jeho zápal bojovníka snažícího se přemoci sílu klerikalismu či ideologizovaného náboženství, která byla v jeho době stále ještě veliká. Poněkud závažnější je ovšem to, že Hume promítl svou antireligiózní averzi i do svých historických spisů, čímž porušil zásadu historické objektivity sine ira et studio. ${ }^{86}$ Je proto třeba připomenout, že John Stuart Mill nebyl úplně na omylu, když prohlásil, že ohled na pravdu neformoval žádnou část Humova charakteru.

Nutno tedy konstatovat, že Hume fenoménu náboženství (a zejména pak křest́anství) neporozuměl ani v té míře jako Marx, který byl sice také proslulým ateistou, avšak přesto byl s to pronést výrok, že „náboženství je citem bezcitného světa“, v němž aforisticky shrnuje Hegelovo učení o "nešt'astném vědomí“ i jeho feuerbachovské rozpracování. Hlavní Humovou chybou je, že pohnutky, které vedou člověk k náboženství, jsou sekundární a nahodilé; jeho pozice tudíž stojí $\mathrm{v}$ naprostém protikladu vůči nesrovnatelně hlubšímu stanovisku Kantovu, v souladu s nímž je vztah k absolutnu (a podobě apriorní ideje Boha a této ideji odpovídajícího rovněž apriorního postulátu praktického rozumu) nejen nutným a univerzálním rysem lidské mysli, nýbrž i rysem, který všechny ostatní funkce mysli integruje a

\footnotetext{
${ }^{84}$ A právě pro mentalitu dřivějšího zázračného dítěte bylo patrně velmi tíživou skutečností, že v první třetině jeho působení byl za největšího britského filosofa pokládán Francis Hutcheson, ve druhé třetině pak Adam Smith a na sklonku Humova života zase Thomas Reid. teprve potomstvo jej vyzvedlo na piedestal největšího britského filosofa všech dob.

${ }^{85}$ Srv. James Orr, ibid., str. 198. Jestliže však Orr uvádí jako obzvláště typický příklad Humovy přehnané kritičnosti vůči křest́anství jeho tvrzení, že „zuřivé pronásledování křestanå mělo svoji př́činu zejména $\mathrm{v}$ neprožretelném fanatismu a bigotnosti prvních propagátorů této sekty“" pak musíme dát za pravdu spiše Humovi, protože novější historický výzkum potvrdil, že působení prvních křestáanů, přesvědčených, že jsou jedinými nositeli absolutní pravdy, se značně lišilo od idylického obrazu raně-křest’anských komunit, rozšřřeného hlavně pod vlivem Sienkiewiczova románu Quo vadis.

${ }^{86} \mathrm{~V}$ citovaném Orrově spisu můžeme najít i výčet dalších Humových prohřešků proti principu historické objektivity včetně kritické analýzy chyb Humových metodických přistupů podané lordem Macaulayem (James Orr, ibid., str. 228.) I když nelze než souhlasit s Humovou (a ještě více s Burkovou) kritikou revolucí uskutečňovaných na základě ideologií a tyto ideologie uskutečňujících, přesto je třeba přiznat, že tendenčnost Humova dějepisectví celkový účin jeho kritiky oslabuje (a to navzdory tomu, že zvyšuje její bezprostřední impresivnost).
} 
reguluje. ${ }^{87}$ I pro oblast filosofie náboženství tedy platí, že hlavní Humovou zásluhou je, že probudil Kanta z dogmatického spánku.

Co se týče Humova přesvědčení, že člověk, ve své přirozenosti dobrý, nepotřebuje náboženskou sankci svého mravního jednání, bylo dlouho zastáváno Humovým velkým obdivovatelem Hayekem v podobě tvrzení, že mravní principy nezbytné pro fungování tržního řádu se uplatňují a udržují v modu nereflektované tradice; Hayek však později, jak dokládá jeho text nazvaný „Náboženství a strážci tradice“, přesto dospěl k poznání o významu náboženské sankce mravnosti; připouští také, že pozitivní v tomto smyslu může být i pověra, protože je "pro svět lepší, když lidé jednají správně ze špatných motivů, než když činí zlo s těmi nejlepšími úmysly“. 88

Je třeba bohužel zmínit i Humovo nešt’astné doporučení (znějící jako autoritativní verdikt), aby všechny knihy, které neobsahují abstraktní úvahy o kvantitě a čísle nebo zkušenostní úvahy o „faktických okolnostech a jsoucím“ byly předány plameni, protože nemohou obsahovat "nic než sofistiku a klam“" ${ }^{89}$ Vzhledem k tomu, že naplnění tohoto doporučení by postihlo všechny Humovy filosofické spisy, lze je chápat pouze jako projev Humova smyslu pro absurdno a groteskno (spjatý s onou podobou "anglické nemoci“, jíž patrně trpěl) kombinovaný navíc s rafinovanou sebeironií.90 Bohužel se našli takoví „chudí duchem“, kteří toto doporučení vzali vážně, což vedlo ke vzniku pozitivismu, novopozitivismu, tzv. analytické filosofie a dalších jiných mentálních nepravostí, jež nás nepřestávají trápit ani v 21. století. ${ }^{91}$

\footnotetext{
${ }^{87} \mathrm{~V}$ této souvislosti je nanejvýš významná Humova myšlenka lsti přírody, tj. myšlenka, že příroda nás „št'astně klame iluzí, že lidský život má nějaký význam“. (D. Hume, Skeptik, in: ibid., str. 179.) Když vezmeme v úvahu, že oproti oné iluzi smysluplnosti lidského života stojí u Huma poznání, že „lidské záležitosti podléhají neustálým změnám a revolucím, které dřív nebo později pohltí všechny zákony, vědomosti, knihy a vlády jako rychlý proud, aby se ztratily v nezměrném oceánu hmoty“, pak z toho plyne, že ona iluze smysluplnosti lidského života nemůže mít jinou podobu, než je iluze smyslodajného (nejvýše dobrého) Boha, který je zároveň tvưrcem (iluzorně) nesmrtelné lidské duše. Pokud je dále iluze Boha (čili smysluplnosti lidského života) lstí přírody, musí mít jakožto výtvor přírody apriorní charakter. Uvedeme-li tento konsekvent do kontextu s Humovým výše rozebíraným evolucionismem, dospějeme k závěru, že Hume dospívá k intuici evolučně-aprioristického vysvětlení ideje Boha a naší víry v něj.

88 Srv. Friedrich A. Hayek, ibid., str. 168. (Uvedený výrok je citací z díla Jamesa Frazera Úkol psyché $\mathrm{Z}$ roku 1909.)

${ }^{89}$ Srv. ZR, str. 224. Jestliže - jak upozornil A. J. Ayer - Humova prvotní verze pozitivismu implikuje, že veškeré metafyzické, náboženské a hodnotové soudy jsou kognitivně významuprosté, pak navzdory tomu, že ona zbavenost významu se týká výroků hlásajících jak teismus, tak ateismus, se pozitivismus ukázal jako daleko nebezpečněǰsí pro náboženství než pro bezvěrectví.

${ }_{90} \mathrm{~V}$ Humově sebeironii má patrně svůj původ i jeho časté citování Baconova aforismu „trocha filosofie činí z lidí ateisty; hodně filosofie je s náboženstvím usmiřuje“. (Např. v $P R$, str. 32.)

${ }^{91}$ Podle Husserla je Hume otcem „slabošského pozitivismu, který se vyhýbá filosofickým propastím, nebo je povrchně zakrývá a uspokojuje se úspěchy pozitivních věd a jejich psychologistickým výkladem“. (E. Husserl, ibid., str. 111.)
} 
Prosí-li nás Hume ve výroku, který jsme uvedli jako motto, abychom mu prominuli, že předstíral, že je filosof,92 míní tím, že není „falešným“ filosofem, který na základě autonomie rozumu poskytuje obecenstvu definitivně platné hodnotové soudy mající za cíl překonat hodnotový relativismus předreflexivní sféry. Nezáměrným důsledkem vyslovení tohoto výroku je však upozornění na skutečnost, že Hume není filosofem ani ve zcela rudimentárním významu tohoto slova odkazujícího k mysliteli, který podává koherentní systém myšlenek a který v případě, že překonává jednotlivá svá stanoviska, podává explicitní reflexi vývojové nutnosti přechodi̊ mezi nimi. ${ }^{93}$ Nicméně přes veškerou nesystémovost a inkoherenci, které jsou vlastní jeho dílu jako celku (a které způsobují, že jeho myšlenky jsou vděčným polem zkoumání pro celé generace vykladačů) dospěl Hume k mnoha geniálním náhledům, které - zejména v rozvinuté podobě, kterou jim dali mužové jako Kant a Darwin - víc než kompenzují neblahé pozitivistické dědictví, svázané s jeho jménem.

\footnotetext{
92 Srv. David Hume, Skeptik, in: ibid., str. 170.

93 „Jakkoli úžasný je Humův génius, je politováníhodné, že se s ním nesnoubí přiměřeně velké filosofické ethos. Je to vidět na tom, jak se Hume při svém celém výkladu snaží jemně zastřít protismyslné výsledky a dát jim nevinný význam, ačkoli (v závěrečné kapitole I. dílu Treatise) přece jen líčí ohromné rozpaky, do nichž upadá konsekventně teoretický filosof. Hume se však nepustí do boje s protismyslností (...), aby pronikl $\mathrm{k}$ jednoznačnému sebepochopení a k pravé teorii poznání, ale místo toho setrvává v pohodlné a velmi působivé roli akademického skepticismu." (E. Husserl, ibid., str. 110-111.)
} 


\section{Bibliography}

Augustine Birrell, ed., Boswell's Life of Johnson II, Archibald Constable and Co., Westminster 1896.

James Boswell, Život Samuela Johnsona, Václav Petr, Praha 1930.

Edmund Burke, Úvahy o revoluci ve Francii, Centrum pro studium demokracie a kultury, Praha 1997.

Glen Colburn, ed., The English Malady: Enabling and Disabling Fictions, Cambridge Scholars Publishing, Cambridge 2008.

Charles Darwin, O vzniku druhů přirodním výběrem, Academia, Praha 2007.

Detmar Doering, Die Wiederkehr der Klugheit, Königshausen und Neumann, Würzburg 1990.

François Furet, Francouzská revoluce díl I, Od Turgota k Napoleonovi 1770-1814, Argo, Praha 2004.

Friedrich A. Hayek, Osudná domýšlivost, Sociologické nakladatelství, Praha 1995.

G. W. F. Hegel, Fenomenologie ducha, NČSAV, Praha 1960.

David Hume, Life and Correspondence of David Hume, by John Hill Burton 1846, Edinburgh 1846.

David Hume, „My Own Life“, in: T. H. Green, T. H. Grose, eds., Essays Moral, Political, and Literary by David Hume, Longmans, Green and Co., London 1889.

David Hume, Přirozené dějiny náboženství a Rozmluvy o náboženství přirozeném, Jan Laichter, Praha 1900.

David Hume, Skeptik, in: Filosofický časopis, FÚ AV ČR Praha, 2008/2.

David Hume, Untersuchungen über die Prinzipen der Moral von David Hume, Vídeň, 1883.

David Hume, Zkoumání o lidském rozumu, Svoboda, Praha 1996.

Edmund Husserl, Krize evropských věd a transcendentální fenomenologie, Academia, Praha 1972. 
Thomas Henry Huxley, Hume, English Men of Letters Series, Harper \& Brothers,. New York, 1879.

Gilbert Keith Chesterton, The Everlasting Man, Garden City, NY, 1955.

George Cheyne, The English Malady: or, A Treatise of Nervous Diseases of all Kinds, as Spleen, Vapours, Lowness of Spirits, Hypochondriacal, and Hysterical Distempers, etc., London 1733.

Paul Kingsnorth, "How the English malady became the world's" (http://www.highbeam.com/doc/1P2-10172432.html).

T. G. Masaryk, Moderní člověk a náboženství, Naše Doba IV, 1897.

André Maurois, Dějiny Anglie, Lidové noviny, Praha 2003.

Jules Michelet, Rekové a rebelové sladké Francie, Odeon, Praha 1974.

Felix Müller, David Humes Stellung zum Deismus, Buchdruckerei Robert Noske, Borna-Leipzig 1906.

Zdeněk Nejedlý, T. G. Masaryk III, Melantrich, Praha 1935.

Zdeněk Novotný, David Hume a jeho common life. Historie jedné dezinterpretace, in: Filosofický časopis, FÚ AV ČR Praha, 2010/3.

James Orr, David Hume and His Influence on Theology and Philosophy, T \& T. Clark, Edinburgh 1903.

Ján Pavlík, Spontánni geneze jazyka, Professional Publishing, Praha 2010.

Ferdinand Peroutka, Budování státu II, Lidové noviny, Praha 1991.

Adam Smith, Pojednání o podstatě a pưvodu bohatství národi̊, Liberální institut, Praha 2001.

Adam Smith, The Correspondence of Adam Smith, ed. E. T. Mossner, I. S. Ross, Oxford University Press 1987.

M. Alexander Stewart, The Kirk and the Infidel, Lancaster University, 1995; corrected edition, 2001.

Alexis de Tocqueville, Starý režim a revoluce, Academia, Praha 2003.

Wilhelm Windelband, Die Geschichte der neueren Philosophie I, Breitkof \& Härtel, Leipzig 1922. 
John P. Wright, Hume's Treatise of Human Nature, Cambridge University Press, Cambridge 2009. 


\section{E-LOGOS}

ELECTRONIC JOURNAL FOR PHILOSOPHY

Ročník/Year: 2011 (vychází průběžně/ published continuously)

Místo vydání/Place of edition: Praha

ISSN 1211-0442

Vydává/Publisher:

Vysoká škola ekonomická v Praze / University of Economics, Prague

nám. W. Churchilla 4

Czech Republic

13067 Praha 3

IČ: 61384399

Web: http://e-logos.vse.cz

Redakce a technické informace/Editorial staff and technical information:

Miroslav Vacura

vacuram@vse.cz

Redakční rada/Board of editors:

Ladislav Benyovszky (FHS UK Praha, Czech Republic)

Ivan Blecha (FF UP Olomouc, Czech Republic)

Martin Hemelík (VŠP Jihlava, Czech Republic)

Angelo Marocco (Pontifical Athenaeum Regina Apostolorum, Rome, Italy)

Jozef Kelemen (FPF SU Opava, Czech Republic)

Daniel Kroupa (ZU Plzeň, Czech Republic)

Vladimír Kvasnička (FIIT STU Bratislava, Slovak Republic)

Jaroslav Novotný (FHS UK Praha, Czech Republic)

Jakub Novotný (VŠP Jihlava, Czech Republic)

Ján Pavlík (editor-in-chief) (VŠE Praha, Czech Republic)

Karel Pstružina (VŠE Praha, Czech Republic)

Miroslav Vacura (executive editor) (VŠE Praha, Czech Republic) 